OPEN ACCESS

Edited by:

Daoyang Yuan,

Lanzhou University, China

Reviewed by:

Bhaskar Kundu,

National Institute of Technology

Rourkela, India

Zhongtai He,

National Institute of Natural Hazards,

China

*Correspondence:

Zhongyuan Yu

yuyangzi9811@126.com

Na Yin

yinna@cidp.edu.cn

Specialty section:

This article was submitted to Structural Geology and Tectonics,

a section of the journal

Frontiers in Earth Science

Received: 08 November 2021

Accepted: 24 January 2022

Published: 15 February 2022

Citation:

Yu Z, Yin N, Xiao P and Chen B (2022)

Co-Seismic Surface Ruptures of the CE 1738 M 7.6 Dangiiang Earthquake

Along the NW Continuation of the

Xianshuihe Fault Zone and Tectonic

Implications for the Central

Tibetan Plateau.

Front. Earth Sci. 10:810891.

doi: 10.3389/feart.2022.810891

\section{Co-Seismic Surface Ruptures of the CE 1738 M 7.6 Dangjiang Earthquake Along the NW Continuation of the Xianshuihe Fault Zone and Tectonic Implications for the Central Tibetan Plateau}

\author{
Zhongyuan $\mathrm{Yu}^{1,2 *}$, Na Yin ${ }^{2,3 *}$, Peng Xiao ${ }^{1,2}$ and Baixu Chen ${ }^{1,2}$ \\ ${ }^{1}$ College of Earth Sciences, Yanjiao Development Zone, Institute of Disaster Prevention, Sanhe, China, ${ }^{2}$ Hebei Key Laboratory of \\ Earthquake Dynamics, Sanhe, China, ${ }^{3}$ College of Ecology and Environment, Yanjiao Development Zone, Institute of Disaster \\ Prevention, Sanhe, China
}

The role of large-scale strike-slip faults in high-elevation areas in absorbing the strain resulting from plate convergence has yet to be scientifically understood. The Dang Jiang Fault (DJF), as the NW continuation of the Xianshuihe Fault Zone (XFZ) in the central Qinghai-Tibetan Plateau, may provide an excellent testing ground for this question, given its high slip rate, sparse vegetative cover, minimal modification, and possible relationship with the CE 1738 Dangjiang destructive earthquake. However, co-seismic surface ruptures and seismotectonics remain in dispute because of inconvenient transportation and lack of oxygen at high altitudes. Thus, field investigations are conducted here to determine co-seismic surface ruptures. The newly synthesized data from geologic observations, historical record reviews, geomorphic mapping, trench logging, and sample dating indicate that the CE 1738 Dangjiang earthquake produced an $100 \mathrm{~km}$ long surface rupture that includes offsets of gullies, linear scarps and troughs, sag ponds, en echelon fractures, and pressure ridges. The magnitude is re-estimated as $M 7.6$, with average and maximum strike-slip displacements of $\sim 2.1 \pm 0.1 \mathrm{~m}$ and $\sim 3.5 \pm 0.1 \mathrm{~m}$, respectively. The DJF has undergone multiple seismic faulting events, and the linear fitting surface displacement rate in the Holocene is $~ 6.3 \pm 1.9 \mathrm{~mm} / \mathrm{yr}$ with a $95 \%$ confidence interval. This study implies that the seismic hazard of the DJF cannot be underestimated given that its elapsed time is close to or beyond the recurrence interval of major earthquakes and that the oblique convergence of the Qiangtang Block might be accommodated by the clockwise rotation of the block through repeated left-lateral strike-slip movements along the southern boundary of the Bayan Har Block.

Keywords: co-seismic surface rupture, CE 1738 dangjiang earthquake, central tibetan plateau, repeated left-lateral strike-slip movement, seismic hazard 


\section{INTRODUCTION}

The large-scale strike-slip faults in continental interiors have played important roles in the process of the adjustment and absorption of tectonic deformation that has resulted from the collision between the Indian plate and the Eurasian plate since $45 \pm 5 \mathrm{Ma}$ (Molnar and Tapponnier, 1975; Rowley, 1996; Tapponnier et al., 2001; Lin et al., 2002; Yin, 2010), although their geodynamic processes have yet to be thoroughly understood. The $\sim 1,400 \mathrm{~km}$-long Xianshuihe Fault Zone (XFZ), extending from southern Yunnan Province northwest through Sichuan into Qinghai in the central Tibetan Plateau, is a typical example among these great strike-slip faults and is probably currently the most active strike-slip fault system within China (Allen et al., 1991; Deng et al., 2002; Deng et al., 2007; Zhang et al., 2003) (Figure 1). In recent years, the XFZ has released strain energy with an average left-lateral slip rate of $\sim 10 \mathrm{~mm} / \mathrm{yr}$ (Wen et al., 2003) and more than 14 destructive earthquakes $(M \geq 7)$ (Figure 1). Although many achievements in the middle and eastern sections of the XFZ have been attained by geologists around the world, the active tectonics and seismogenic behavior, recurrence interval of great earthquakes, slip rate, and maximum magnitude estimation along the western portion of the XFZ remain debated (Wang et al., 2007). In fact, these basic data are crucial for assessing the seismic hazard and activity habit along the whole structure, as well as for deciphering the strain distribution and tectonic deformation model in the central Tibetan Plateau.

The Dang Jiang Fault (DJF, also called the Dangjiang section of the Ganzi-Yushu Fault Zone), which is the westernmost continuation of the XFZ in the central Qinghai-Tibetan Plateau, provides a unique natural laboratory for the acquisition of these data. Historical accounts and paleoseismic studies show that more than seven great earthquakes have occurred along the western portion of the XFZ, all with distinctive co-seismic surface ruptures. These studies also suggest that co-seismic rupture lengths at the surface vary from $\sim 30$ to $180 \mathrm{~km}$ and that the average and maximum coseismic left-lateral displacements are approximately 1.5-2.5 and $5 \mathrm{~m}$, respectively (Zhou et al., 1996; Zhou et al., 1997; Wen et al., 2003; Chen et al., 2010; Lin et al., 2011). In particular, the CE 1738 Dangjiang earthquake, despite matching the area crossed by the

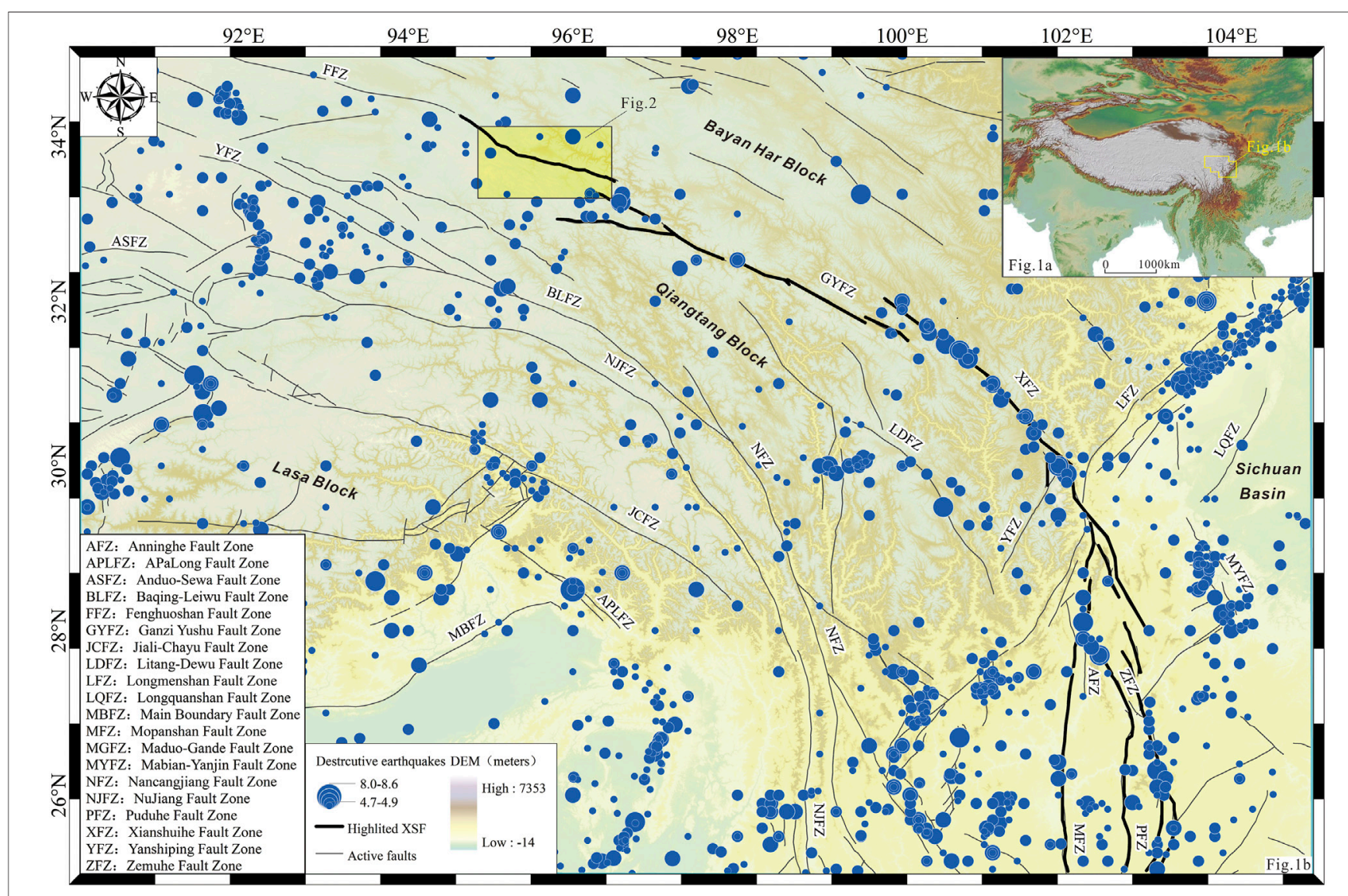

FIGURE 1 | Sketch map of earthquake distribution and geological background of the study area. (A) Topographic relief of the Tibet Plateau. (B) Seismotectonic map of the Xianshuihe Fault Zone (XFZ) and the surrounding area. Black bold lines in the map represent the XFZ structure. Blue solid circles represent the destructive earthquake epicenters $(M s \geq 4.7$, epicenters are from the China Earthquake Networks Center, 2020). Red solid lines represent the main active fault traces (Deng et al., 2007). The light yellow rectangle on the north side of the image represents the scope of the study region. The inset at the lower left shows the abbreviation of regional active faults illustrated in the map. 
TABLE 1 | Measured ages of samples from trenches and outcrops along the DFZ.

\begin{tabular}{|c|c|c|c|c|}
\hline No. in the field & No. in laboratory & Equivalent dose(Gy) & Dose rate (Gy/ka) & Age (ka BP) \\
\hline DJFZOSL-01 & FZ-22 & $3.23 \pm 0.32$ & $3.62 \pm 0.12$ & $1.10 \pm 0.09$ \\
\hline DJFZOSL-02 & FZ-14 & $30.75 \pm 1.86$ & $3.62 \pm 0.10$ & $10.47 \pm 0.58$ \\
\hline DJFZOSL-07 & FZ-31 & $0.93 \pm 0.22$ & $3.60 \pm 0.10$ & $0.32 \pm 0.06$ \\
\hline DJFZOSL-10 & $\mathrm{FZ}-15$ & $1.17 \pm 0.39$ & $4.77 \pm 0.10$ & $0.40 \pm 0.08$ \\
\hline DJFZOSL-11 & FZ-12 & $7.04 \pm 2.13$ & $2.99 \pm 0.13$ & $2.35 \pm 0.71$ \\
\hline DJFZOSL-12 & FZ-07 & $9.74 \pm 0.55$ & $3.99 \pm 0.10$ & $2.44 \pm 0.14$ \\
\hline DJFZOSL-20 & FZ-04 & $1.04 \pm 0.25$ & $4.01 \pm 0.10$ & $0.26 \pm 0.06$ \\
\hline DJFZOSL-22 & $F Z-28$ & $0.97 \pm 0.20$ & $3.84 \pm 0.10$ & $0.33 \pm 0.05$ \\
\hline DJFZOSL-29 & FZ-09 & $52.88 \pm 3.21$ & $4.78 \pm 0.15$ & $11.18 \pm 1.07$ \\
\hline DJFZOSL-30 & $\mathrm{FZ}-19$ & $2.00 \pm 0.36$ & $3.63 \pm 0.10$ & $0.68 \pm 0.10$ \\
\hline DJFZOSL-41 & $\mathrm{FZ}-27$ & $14.23 \pm 0.63$ & $4.62 \pm 0.17$ & $3.08 \pm 0.50$ \\
\hline DJFZOSL-42 & FZ-29 & $12.24 \pm 1.10$ & $3.54 \pm 0.15$ & $3.46 \pm 0.45$ \\
\hline DJFZOSL-50 & FZ-47 & $1.53 \pm 0.07$ & $3.35 \pm 0.13$ & $0.46 \pm 0.03$ \\
\hline DJFZOSL-51 & $\mathrm{FZ}-48$ & $13.95 \pm 0.48$ & $3.71 \pm 0.16$ & $3.76 \pm 0.20$ \\
\hline No. in the field & Analyzed Material & IRMS $\delta 13 C$ & Conventional Age & 2 Sigma calibration age \\
\hline DJFZ- ${ }^{14} \mathrm{C}-04$ & Organic sediment & $-25.5 \%$ & $770 \pm 30 \mathrm{BP}$ & Cal. BP 729 to 668 \\
\hline DJFZ- ${ }^{14} \mathrm{C}-06$ & Organic sediment & $-24.3 \%$ & $3,380 \pm 30 \mathrm{BP}$ & Cal. BP 3696 to 3,650 \\
\hline DJFZ- ${ }^{14} \mathrm{C}-10$ & Charred material & $-22.0 \%$ & $1,270 \pm 30 \mathrm{BP}$ & Cal. BP 1287 to 1,175 \\
\hline
\end{tabular}

DJF, has some still unverified issues: the characteristics of coseismic surface deformation and the possible associated maximum magnitude. Both of these factors directly influence our understanding of the geodynamic process of strain adjustment and active tectonics of the whole XFZ, as well as the assessment of the earthquake potential along the structure and in the neighboring area of the central region of the QinghaiTibetan Plateau.

Thus, the main purposes of this study are to investigate the coseismic surface ruptures of the 1738 Dangjiang earthquake, to study the active behavior of the DJF in the late Quaternary, and to discuss its tectonic implications for the seismic hazard and strain partition along the southern boundary of the Bayan Har Block in the central Tibetan Plateau area.

\section{TECTONIC SETTING}

Broadly speaking, the XFZ (in the broad sense) is a well-known NWSE trending seismogenic structure within the Tibetan Plateau, and more than 60 earthquakes with magnitudes greater than 6.0 have occurred since CE 1500 because of repeated left-lateral slippage along the structure (Allen et al., 1991; Lin et al., 2002; Wen et al., 2003; Wang et al., 2007; Wen et al., 2008; Li et al., 2012) (Figure 1). The structure is composed of many subsections from southeast to northwest, including the Zemuhe Fault Zone (ZFZ), the Anninghe Fault Zone (AFZ), the Xianshuihe Fault Zone (XFZ, in the narrow sense), and the Ganzi-Yushu Fault Zone (GYFZ) (Figure 1). Previous studies on seismology (Wang and Burchefiel, 2000), thermochronology (Arne et al., 1997; Xu and Kamp., 2000), geodesy (King et al., 1997), and granites or volcanic rocks (Roger et al., 1995; Wang et al., 1998) have shown that their formation times, evolutionary processes, and deformation features are not exactly the same.

Our study area is located in a high mountain region along the northwestern section of the large-scale left-lateral strike-slip GYFZ, which is viewed as the northwestern continuation of the XFZ, at an average elevation of $\sim 5,300 \mathrm{~m}$ in the central Tibetan Plateau (Figure 1). The GYFZ strikes NW-SE with a length greater than $\sim 550 \mathrm{~km}$ and forms the southern tectonic boundary of the Bayan Har Block with other branches of the XFZ (Figure 1). The GYFZ overlaps the NW end of the XFZ with a left en echelon stepover of approximately $40 \mathrm{~km}$ (Allen et al., 1991). Field geological observations and GPS velocity inversion results reveal that the average left-lateral strike-slip rate of the GYFZ in the Holocene is 4-13 mm/yr (Wang et al., 2001; Lin et al., 2002; Peng et al., 2006; Wang et al., 2007). The basement in this study area consists mainly of Triassic limestone, sandstone, mudstone, and shale with volcanic rocks (Lin et al., 2011), while the Cenozoic strata are dominated by Paleogene purple coarse-grained sediments, Neogene purple finegrained lacustrine sediments, and Quaternary unconsolidated deposits. Previous seismological studies have revealed that modern and historical destructive earthquakes, together with paleoearthquakes along the faults, have ruptured these branches of the GYFZ with variable co-seismic surface rupture sizes and distinctive geomorphic features (Zhou et al., 1997; Lin et al., 2011; Li et al., 2012).

\section{METHOD AND DATA}

In this study, high-resolution satellite images and digital topographic data are first used to interpret the morphology of the DJF. These data mainly include web-based Google Earth images and $30 \mathrm{~m}$ resolution SRTM (Shuttle Radar Topography Mission) data, both of which are used to digitally map individual structures and tectonic features using ESRI ArcMap software. Then, we investigated the Holocene activity of the DJF through tectonic geomorphic surveys, trench excavation, and $\log$ and laboratory chronology tests. Finally, we analyzed the coseismic surface ruptures of the CE 1738 M 7.6 Dangjiang earthquake and discussed its slip rate in the Holocene and the implications for earthquake hazards along the whole XFZ, as well as for tectonic deformation characteristics and possible strain-distribution processes in the central Tibetan Plateau. 


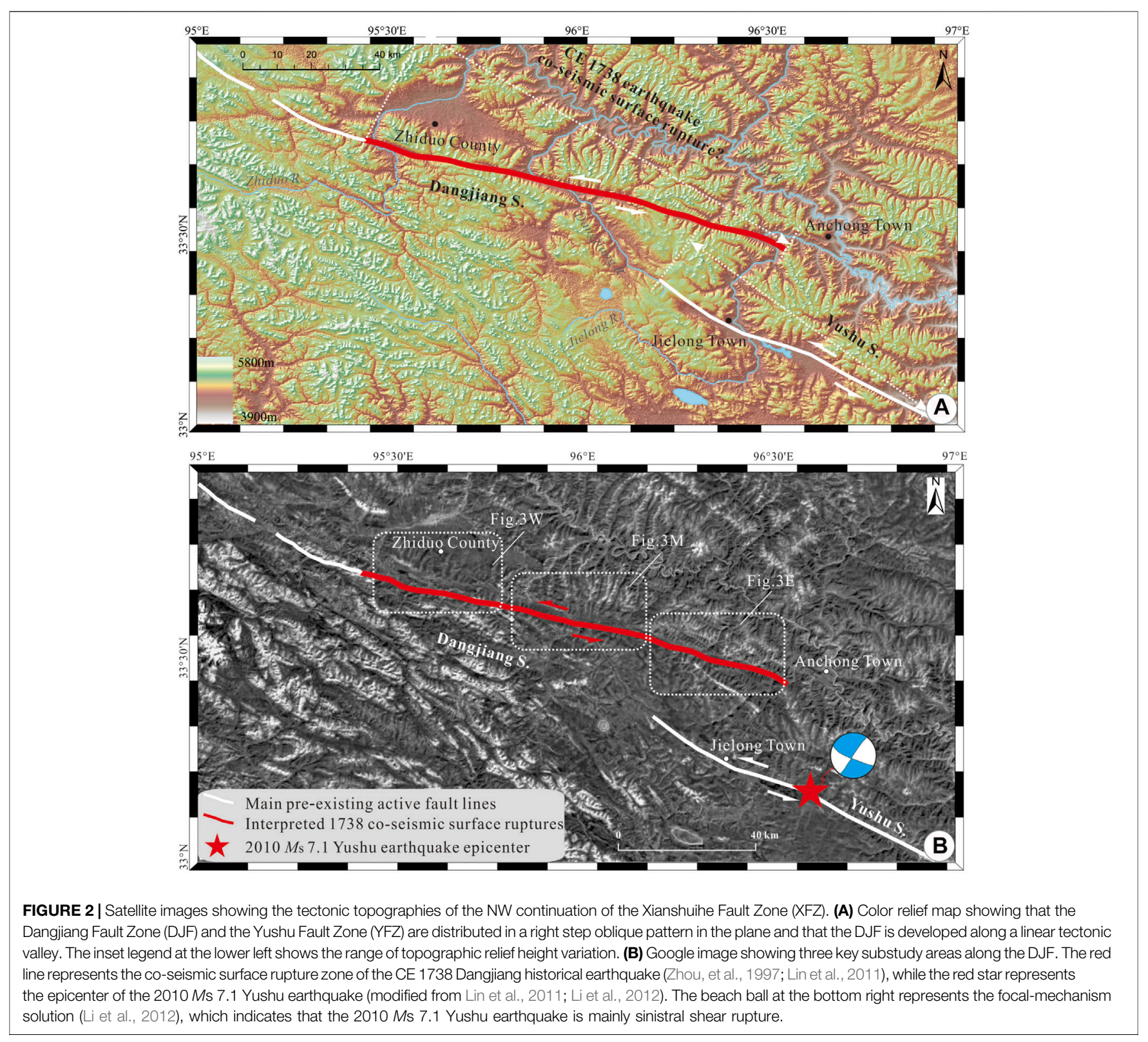

Geomorphic markers, such as fault scarps, stream channels, gullies, small ditches, and river terraces, were mapped and integrated by trench excavation and field surveys. Trench walls were cleaned and logged in detail and then interpreted in the field and laboratory. Offsets were jointly measured by a laser rangefinder and a steel tape. In particular, UAV (unmanned aerial vehicle, Phantom four Manufactured by SZ DJI Technology Co., Ltd.) aerial survey technology is applied in this field survey, which is the first to obtain high-precision displacement-distribution data and tectonic-deformation images in this structure thus far.

Two kinds of dating methods are used in this research: optically stimulated luminescence (OSL) and 14C, and a total of seventeen valid dating results were used in this paper (Table 1). The OSL samples were jointly measured by LinYi University, Institute of Geology of China Earthquake Administration, the
Institute of Disaster Prevention in China, and the sensitivitycorrected multiple aliquot regenerative-dose (SMAR) method was adopted. All tests were conducted using a Daybreak 2,200 automated OSL reader equipped with a combined blue (470 \pm $5 \mathrm{~nm})$ and infrared $(880 \pm 80 \mathrm{~nm})$ LED OSL unit and an Am-241 alpha source $(0.062 \mu \mathrm{m}-2 \mathrm{~s}-1)$ for irradiation (Yu et al., 2018). $14^{\circ} \mathrm{C}$ dating was completed at the Beta Analytic Laboratory (United States) with four in-house NEC accelerator mass spectrometers and four Thermo IRMSs. Conventional radiocarbon ages were calculated using the Libby half-life (5,568 years) corrected for the total isotopic fraction and were used for calendar calibration where applicable.

Unless otherwise specified, all earthquake records and active faults were collected from the China Earthquake Networks Center (2019), Gu, (1983), the Editorial Board of Annals of Sichuan 


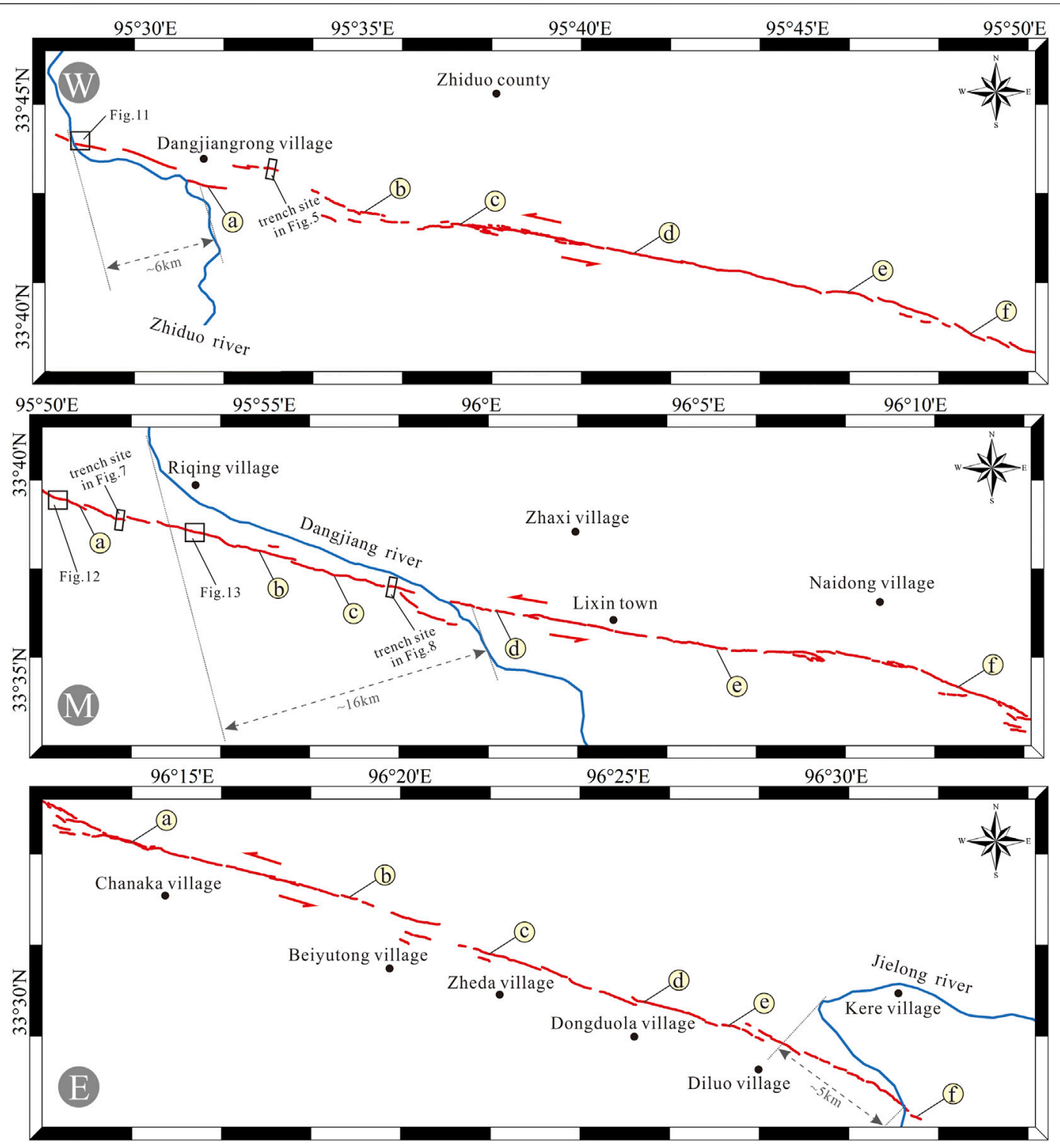

FIGURE 3 | Fine fault geometries interpreted based on high-resolution satellite images and field observations. The red lines represent the co-seismic surface rupture traces of the CE 1738 Dangjiang historical earthquake. The blue solid lines represent the regional deflected rivers. The capital letters of W, M, and E in the map represent the western, middle, and eastern sections of the DJF, respectively, and the marks from(a, b, c-f) to correspond to the locations of the photographs in Figure 4 , Figure 6, and Figure 9, respectively.

Province (1998), and Deng et al. (2007), and previous research data also provide appropriate references in this study (Zhou et al., 1996; Zhou et al., 1997; Wen et al., 2003; Chen et al., 2010; Lin et al., 2011; Li et al., 2012; Li et al., 2016; Wu et al., 2017).

\section{RESULTS}

Field investigation reveals that the strike of the DJF is oriented more east-west than other branches of the XFZ and can be traced for $\sim 170 \mathrm{~km}$ in length (Figure 1 and Figure 2). The DJF ends to the east near Anchong town (Figure 2), and an $\sim 20 \mathrm{~km}$ wide uplift area can be observed near Jielong town because the Yushu fault overlaps the southeastern end of the DJF with a right en echelon stepover of approximately $25 \mathrm{~km}$. Previous studies show that this uplift might have hampered the surface rupture propagation of the Ms 7.1 Yushu earthquake on 14 april 2010 (Lin et al., 2011) (Figure 2). At its northwestern extremity, the DJF connects with the FFZ (Fenghuoshan Fault Zone) and then extends into the complex and little-studied Hoh Xil region (Allen et al., 1991) (Figure 1).

The historical earthquake that occurred in Yushu near Qinghai Province in CE 1738 caused 157 family members to be seriously injured and approximately 500 or 261 people to die 



FIGURE 4 | Diagrammatic features of the CE 1738 co-seismic surface ruptures along the western section of the DJF. Red arrows represent the distribution of the latest co-seismic characteristics, while the black arrows delineate the distribution of the older fault scarp. The azimuth angles in the maps represent the section direction. Note the scale difference in each picture. Pictures from, to correspond to the investigated sites in Figure $\mathbf{3}$ W. (A) Fault scarp, trough, and depressions developed within unconsolidated alluvial and pluvial sediments, which are duplicated in a preexisting structure zone. Note the youngest gully terrace was vertically dislocated by approximately $0.5 \pm 0.1 \mathrm{~m}$, while the height of the older fault scarp is of $\sim 1.6 \pm 0.2 \mathrm{~m}$; (B) A gully was offset (by $9.4 \pm 0.4 \mathrm{~m}$ ) by a preexisting fault and co-seismic surface ruptures where a fault scarp was observed with a height of $\sim 3.0 \pm 0.2 \mathrm{~m}$ at a site located $\sim 1 \mathrm{~km}$ northwest of the gully; (C) Co-seismic surface ruptures in a preexisting fault depression developed along a fault trough accompanied by a geomorphic scarp with a height of $0.9 \pm 0.1 \mathrm{~m}$; (D) Fresh alternating en echelon fractures and pressure ridges (marked by white arrows) are observed in the same direction with the preexisting fault (delineated by red arrows); (E) One gully was horizontally offset (by $2.5 \pm$ $0.1 \mathrm{~m}$ ) by the preexisting fault, while the older gully was abandoned with accumulated dislocations $\sim 5.1 \pm 0.2 \mathrm{~m}$. Additionally, an $\sim 2.8 \pm 0.2 \mathrm{~m}$-high geomorphic scarp and depression were observed along fault; (F) Co-seismic surface ruptures in a preexisting graben with a breadth of $\sim 12.0 \pm 0.5 \mathrm{~m}$ along the valley.

(Compiling Committee of Annals of Qinghai Province, 1998; Yuan et al., 2011), and textual research and field investigations hint that the earthquake resulted in at least $\sim 50 \mathrm{~km}$ surface rupture along the Dangjiang section of the GYFZ (Zhou et al., 1996; Zhou et al., 1997). In this study, the co-seismic surface rupture traces of the CE 1738 Dangjiang earthquake were first mapped through integrated data, such as the interpretation of satellite images (Figure 2 and Figure 3), previous studies (Zhou et al., 1996; Zhou et al., 1997; Yuan et al., 2011), and our field observations. The strike-slip fault activity is shown by deflected gullies, dislocated ditches, linear scarps, fault troughs, shutter ridges, sag ponds, and mole tracks. Furthermore, according to their main differences in co-seismic deformation and geomorphic characteristics, the whole co-seismic rupture line can be divided into three different sections: the western segment, the middle segment, and the eastern 

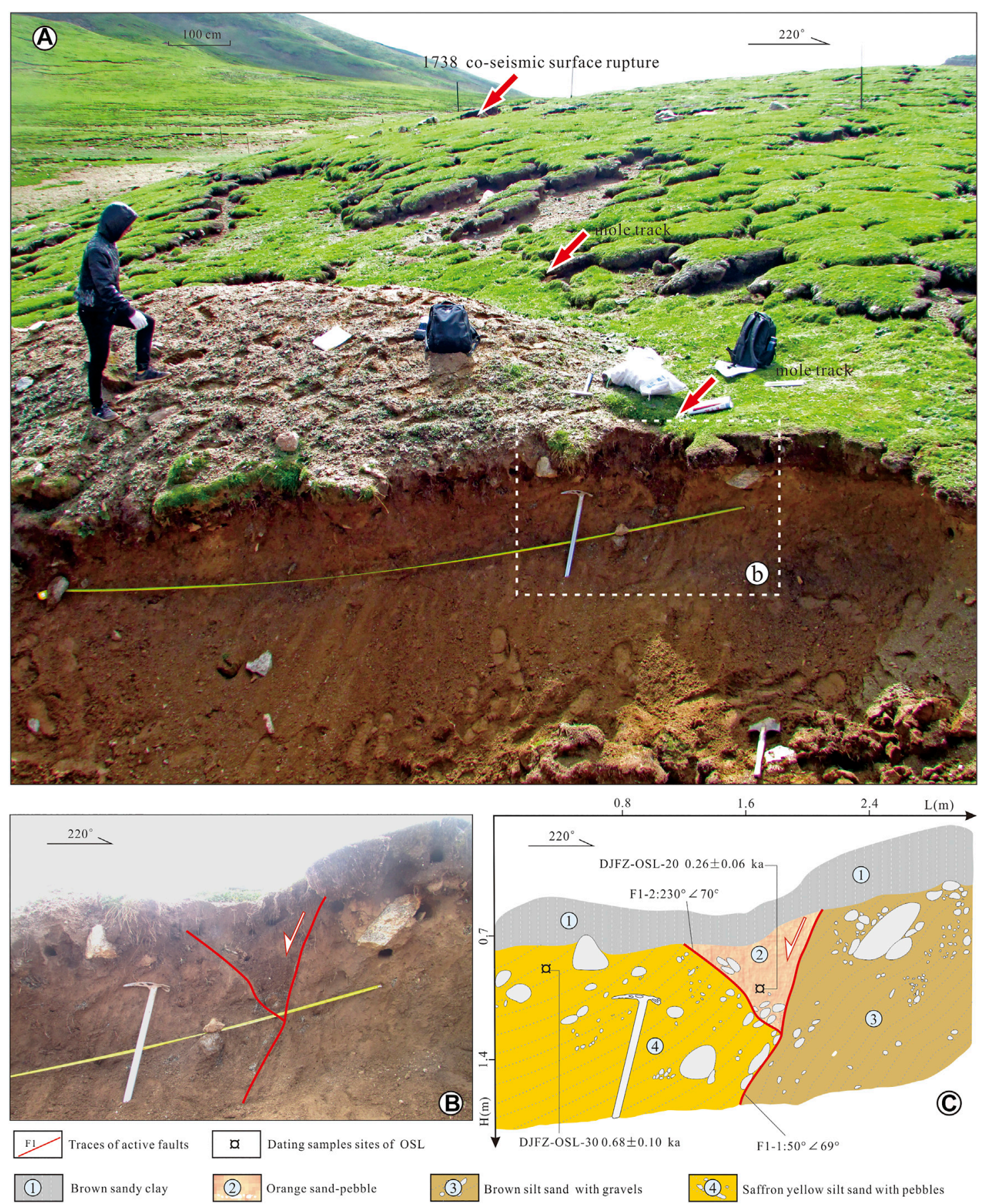

FIGURE 5 |West wall logs of the trench excavated near Dangjiangrong village, and the site of the trench is marked in Figure $\mathbf{3}$ W. (A) Tectonic geomorphic features of the DJF near Dangjiangrong village; (B) Original profile of the west wall (Courtesy of Li et al., 2012, unpublished results); (C) Interpretation map of the west wall. Fault F1 cuts the sediments of Units three to four and is overlain by Unit 1, while the wedge shape of Unit 2 may represent rapid transient accumulation after the earthquake (see the text for details). Fresh mole track structures are observed in the wall. Note the ice-axe in maps for scale.

segment (Figure 2 and Figure 3). Each fault segment is made up of several strands with changing rupture lengths from dozens of meters to several kilometers, most of which are spread out in an en echelon pattern at the surface with an average width ranging from 5 to $35 \mathrm{~m}$ (Figure 3).

\section{The Western Segment of the DJF}

High-resolution satellite images and field observations reveal that the western segment of the DJF terminates at Dangjiangrong village at its northwestern tip with a length of $\sim 36 \mathrm{~km}$ (Figure 3 $\mathrm{W})$. The co-seismic surface rupture features produced by the CE 

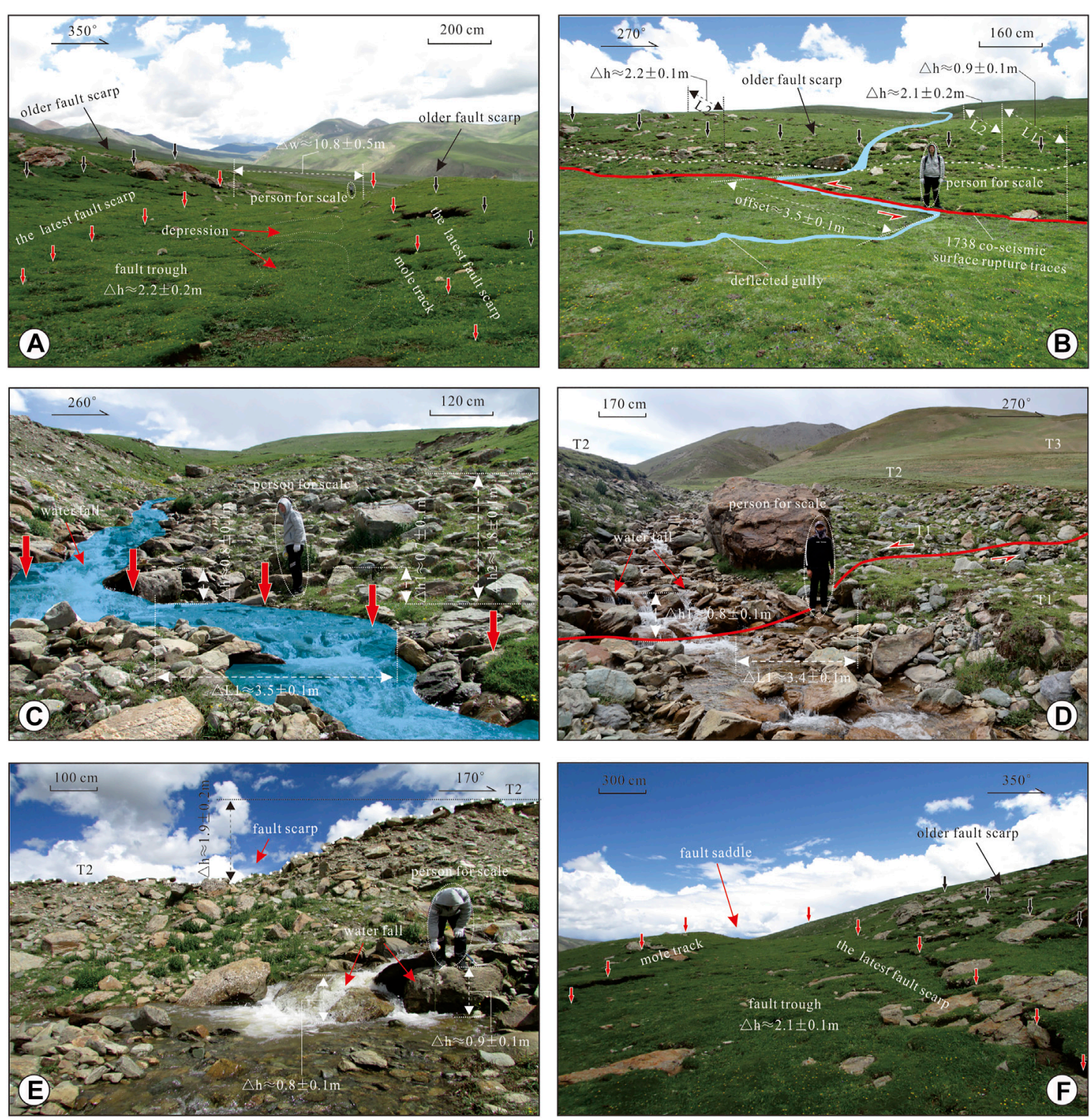

FIGURE 6 | Photographs of representative tectonic landforms of the DJF and CE 1738 co-seismic surface ruptures in the middle section of the structure. Arrows represent the distribution of tectonic characteristics such as fault scarps, mole tracks, and depressions, while the red arrows delineate the latest tectonic deformation. The azimuth angles in the photographs represent the section direction. Note the difference in each scale of the picture. Pictures from, to correspond to the locations of the photographs in Figure 3 M. (A) An $\sim 2.2 \pm 0.2$ m-high co-seismic surface scarp in a preexisting graben with a breadth of $\sim 10.8 \pm 0.5 \mathrm{~m}$ along the fault valley; (B) fault scarp and depressions developed within unconsolidated alluvial and pluvial deposits, which are duplicated in a preexisting structure zone. Note the youngest gully terrace was vertically dislocated by approximately $0.9 \pm 0.1 \mathrm{~m}$, which was horizontally deflected or offset by $\sim 3.5 \pm 0.1 \mathrm{~m} ;$ (C) A modern stream was deflected $\sim 3.5 \pm$ $0.1 \mathrm{~m}$ and vertically offset $\sim 0.8 \pm 0.1 \mathrm{~m}$ (the height of the waterfall drop in the map basically represents the vertical displacement of the latest co-seismic surface rupture), while the higher geomorphologic surface that consists of boulders and gravels was vertically displaced $\sim 1.8 \pm 0.1 \mathrm{~m}$ on the preexisting structure zone; (D) A modern valley flat was deflected $\sim 3.4 \pm 0.1 \mathrm{~m}$ and vertically offset $\sim 0.8 \pm 0.1 \mathrm{~m}$ (the height of the waterfall drop in the map basically stands for the vertical displacement of the latest co-seismic surface rupture), note the person in the map for scale; (E) A stream was vertically dislocated (the height of the waterfall drop in the map is measured at $0.9 \pm 0.1 \mathrm{~m}$ ) by a preexisting fault and co-seismic surface ruptures where a fault scarp was observed with a height of $\sim 1.9 \pm 0.2 \mathrm{~m}$ at a site located $\sim 3 \mathrm{~m}$ east of the stream; (F) Fresh mole tracks are observed in the same direction with the preexisting fault zone, and the height of the fault trough is measured at $\sim 2.1 \pm 0.1 \mathrm{~m}$.

1738 Dangjiang earthquake are investigated at six representative observation points and one trench (Figure 4 and Figure 5).

Although nearly all the co-seismic surface ruptures from the CE 1738 Dangjiang earthquake are oriented in the same direction as the preexisting fault zone, the new fracture traces can still be clearly distinguished from the preexisting structure (Figure 4). A series of fault scarps, troughs, and depressions has developed within unconsolidated alluvial and pluvial sediments along the fault, and the heights of the scarps vary from $0.5 \pm 0.1 \mathrm{~m}$ to $3.0 \pm$ $0.2 \mathrm{~m}$ (Figure 4). In particular, fresh alternating en echelon fractures and pressure ridges are observed in the field (Figure 4D), and the thickness of the blocks is mainly affected 

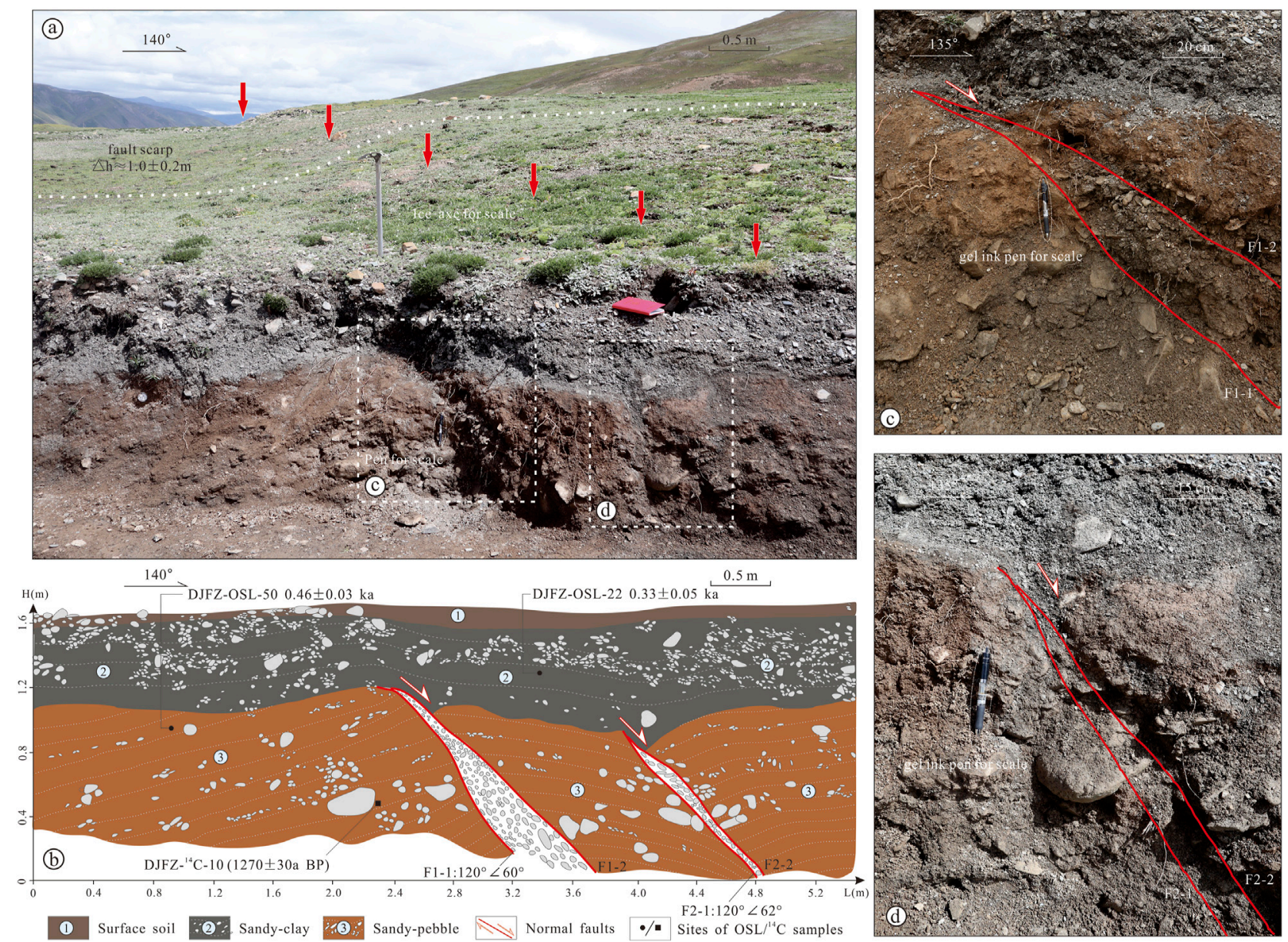

FIGURE 7 | East wall logs of the trench excavated near Riqing village, and the site of the trench is marked in Figure $\mathbf{3}$ W. (A) Tectonic geomorphic features of the DJF near Riqing village. Red arrows in the map delineate the latest surface rupture trace of the DJF with a height of $1.0 \pm 0.2 \mathrm{~m}$. Note the ice-axe in the map for scale. The lateral wall profile of the modern gully cleaned by manual work in the field shows the latest active characteristics of the fault; (B) Interpretation map of the lateral wall profile of the modern gully cleaned. Faults F1-1, F1-2, F2-1, and F2-2 cut the sediments of Units three to two and are overlain by Unit 1 (see the text for details), and the accumulated offset of the faults is $\sim 0.5 \mathrm{~m}$. The gravel in the fault zone is well oriented; photos (C) and (D) are enlarged maps of (A). Red lines in the map indicate the fault traces; note the gel ink pen in the map for scale.

by the depth of frozen ground in this region (Allen et al., 1991). Additionally, the long-term left-lateral strike-slip movement of the fault is well displayed by the repeated deflection or offset of gullies across the structure. A modern gully is offset by $\sim 9.4 \pm$ $0.4 \mathrm{~m}$ because of repeated fault movements where a fault scarp is observed has a height of $\sim 3.0 \pm 0.2 \mathrm{~m}$ at a site located $\sim 1 \mathrm{~km}$ northwest of the gully (Figure 4B). Another modern gully is horizontally offset by $\sim 2.5 \pm 0.1 \mathrm{~m}$, while an older gully is abandoned with an accumulated sinistral displacement of $\sim 5.1 \pm 0.2 \mathrm{~m}$; moreover, an $2.8 \pm 0.2 \mathrm{~m}$-high scarp is observed along the fault zone (Figure 4E). Here, it is proposed that the $\sim 0.5 \pm 0.1 \mathrm{~m}$ vertical offset and the $\sim 2.5 \pm 0.1 \mathrm{~m}$ horizontal offset may be attributed to the recent faulting event that postdates the sedimentation of the unconsolidated alluvial and pluvial deposits, which very likely corresponds to the $\mathrm{CE}$ 1738 Dangjiang event. Meanwhile, the $\sim 9.4 \pm 0.4 \mathrm{~m}$ horizontal displacement and $\sim 3.0 \pm 0.2 \mathrm{~m}$ vertical offset may represent the accumulated displacements that resulted from repeated sinistral slip along the preexisting fault zone and a recent co-seismic surface faulting event.

Furthermore, to study the co-seismic surface ruptures of the CE 1738 Dangjiang historical event and the active tectonics of the DJF in the late Quaternary, a trench was excavated and cleaned across the surface rupture traces near Dangjiangrong village (see Figure $3 \mathrm{~W}$ for location details, associate Professor Li excavated the original trench in 2010 but did not publish it, and he generously provided it to this study). Here, the west wall of the trench is relogged (Figure 5).

The interpreted results reveal that the sediments exposed in the walls consist of alluvial deposits of sand-pebbles and silty mudstone layers with gravels containing organic material with small flakes of charcoal (Figure 5). In general, four distinct stratigraphic units can be identified according to the difference in color and structure of the constituent materials. Unit 1 is the youngest formation and consists mainly of loose brown sandy clay with a thickness of approximately $20 \mathrm{~cm}$. Unit 3 , located on 

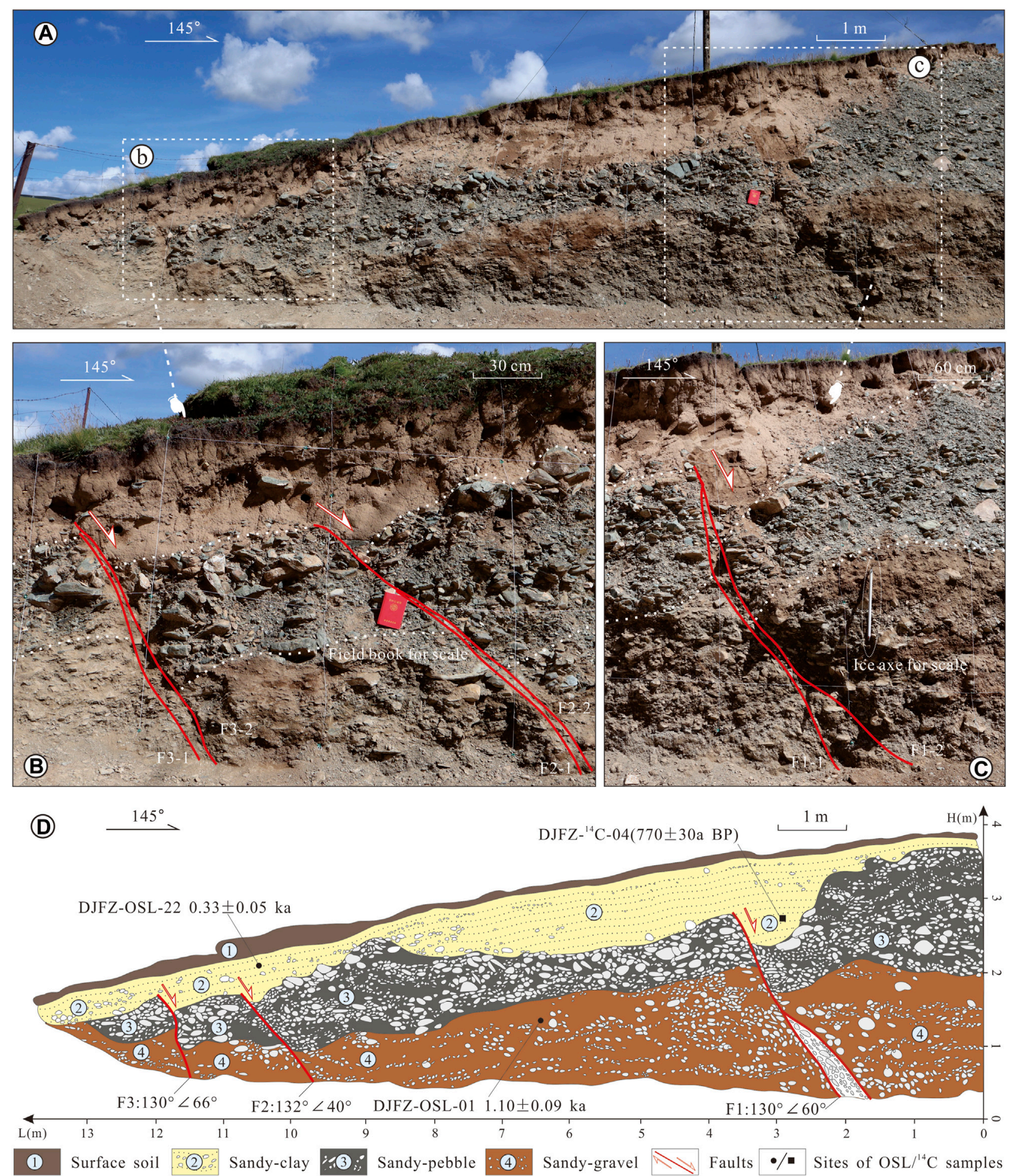

$145^{\circ}$
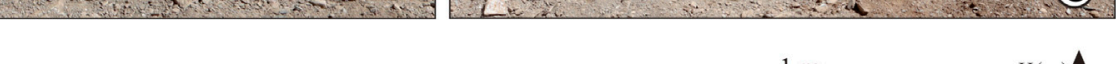

FIGURE $\mathbf{8}$ | Trench excavated near the east of Riqing village on the middle section of the DJF, and the site of the study point is marked in Figure $\mathbf{3}$ M. (A) Original east wall of the trench; photographs (B,C) are enlarged maps of (A). Red lines in the map indicate the fault traces; note the ice axis in the map for scale; (D) interpretation map of the west wall. Faults F1, F2, and F3 cut the sediments of Units four to two and are overlain by Unit 1. Three chronological test results at this point hint that the latest rupture should occur in the CE 1738 Dangjiang historical earthquake with an accumulated co-seismic offset of $\sim 0.9 \mathrm{~m}$ (see the text for details). 

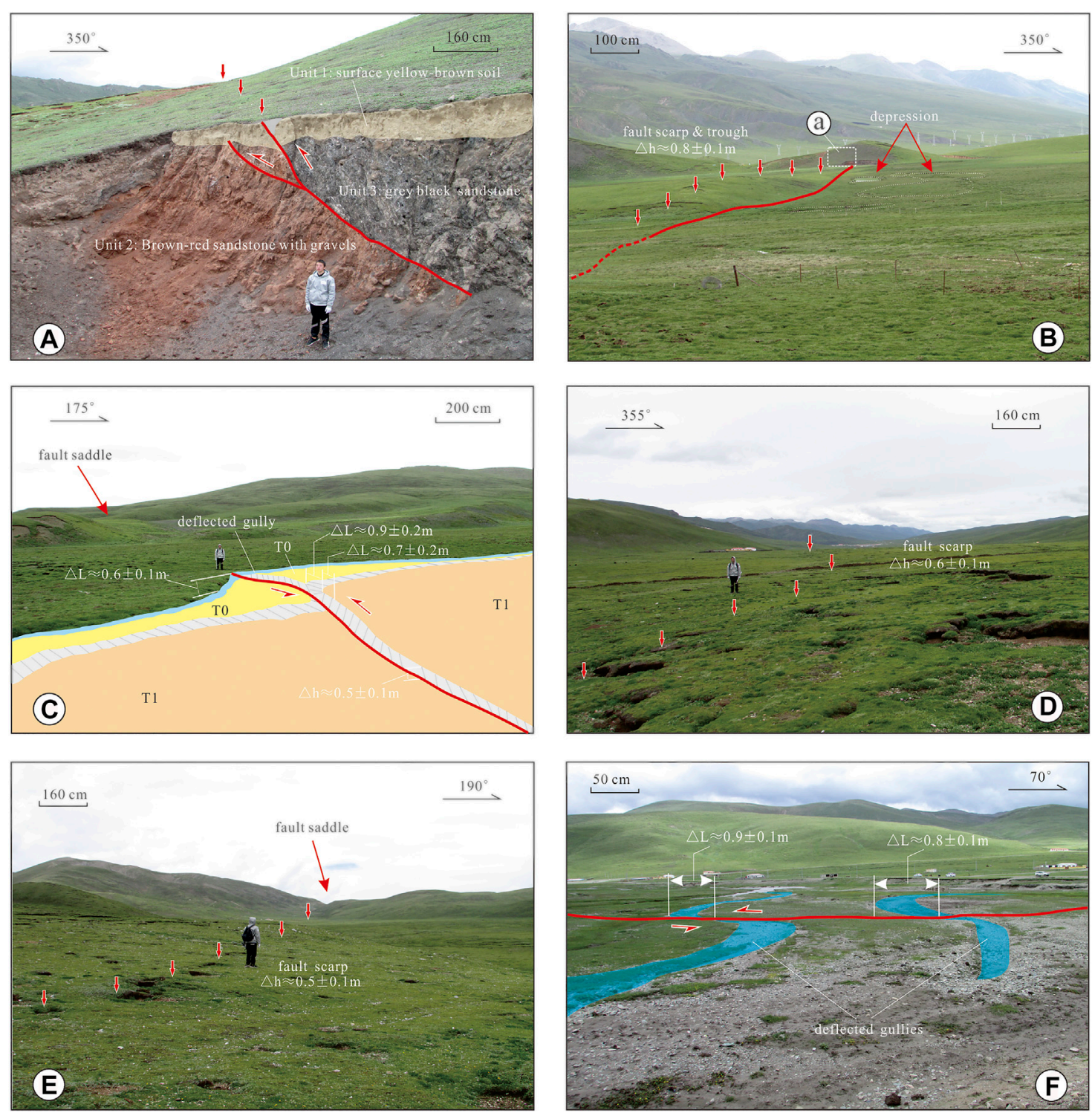

FIGURE 9 | Photographs of representative tectonic landforms of the DJF and CE 1738 co-seismic surface ruptures in the eastern section. Red arrows represent the distribution of co-seismic tectonic characteristics such as fault scarps, mole tracks, and depressions. The azimuth angles in the photographs represent the section direction. Note the difference in each scale. Pictures from, to correspond to the locations of the photographs in Figure $\mathbf{3}$ E. (A) Paleogene brown-red sandstone with gravels in fault contact with Triassic gray black sandstone, and the latest activity of the fault has ruptured the surface modern yellow-brown soil in a thrust way. Note the person in the map for scale; (B) fault scarp, trough and depressions developed within unconsolidated alluvial and pluvial sediments, which are duplicated in a preexisting structure zone. Note that the height of the scarp is $\sim 0.8 \pm 0.1 \mathrm{~m}$; (C) a gully was deflected (by $0.7 \pm 0.2 \mathrm{~m}$ ) by co-seismic surface ruptures where a fault scarp was observed with a height of $\sim 0.5 \pm 0.1 \mathrm{~m}$ on average; (D,E) fault scarp developed within unconsolidated alluvial deposits, and the scarp height is $\sim 0.5 \pm 0.1 \mathrm{~m}$. Fresh mole tracks can be observed in the same direction as the fault zone; (F) two modern gullies were deflected with average horizontal displacements of $\sim 0.8 \pm 0.1 \mathrm{~m}$.

the right side of the section, is composed mainly of brown silt sand with gravels. Unit 4 is distributed on the left side of the section and mainly consists of orange medium and fine sand mixed with gray pebbles. Both the occurrence of Unit 3 and Unit 4 reveal that they have recently undergone intense tectonic deformation. Unit 2 is mainly composed of disordered orange sand-pebbles, whose boundaries are controlled by Unit 3 to the right and Unit 4 to the left and overlaid by Unit 1 (Figure 5).
According to the formation occurrences and cross-cutting relationships between the stratigraphic units mentioned above, the fault traces are sketched and recognized (Figure 5). Both faults are perpendicular to the general trend of the CE 1738 Dangjiang co-seismic surface rupture zone. The main fault F1-1 cuts the sediments of Units 3-4 and is overlain by undeformed Unit 1. Fault F1-2, as the branch of main fault 1-1, has the opposite inclination. Wedge-shaped Unit 2 in Figure 5 should represent rapid transient accumulation shortly after the 


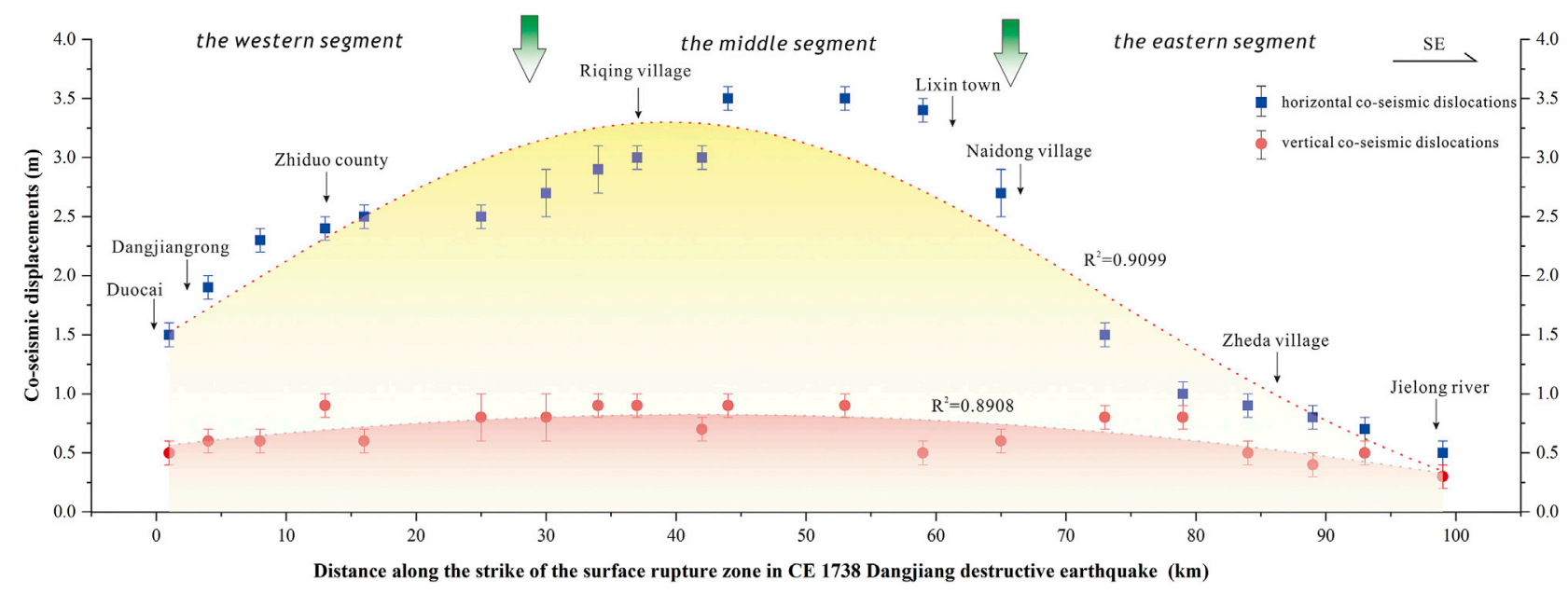

FIGURE 10 | Observed and fitted mean co-seismic displacements in the CE 1738 Dangjiang historical earthquake identified from linear geomorphic markers on high-resolution satellite images and field measurements. The arrows with green gradients represent the approximate position of the segment along the strike of the coseismic surface rupture zone. Blue and red marks represent horizontal and vertical co-seismic dislocations, respectively, along the strike of the surface rupture zone resulting from the CE 1738 Dangjiang M 7.6 surface faulting event (see the text for detailed discussions). The fitted figure shows that the maximum co-seismic displacements are mainly concentrated in the central part of the fault sections and sharply decrease toward the fault ends.

earthquake if the unique colluvial wedge structure and a stacking pattern without stable sedimentary sequences in the units are taken into consideration.

Here, it is proposed that the latest deformation should have occurred after the sedimentation of Units 3-4 and before the deposition of Unit 1 . The age of Unit 2 may approximately represent the age of the latest activity of the DJF. The results of laboratory chronological dating further support this suggestion. The ages of samples from Unit 4 imply that the latest rupture of fault F1-1 should have occurred later than $0.68 \pm 0.10 \mathrm{ka} B P$ (DJFZ-OSL-30) (Figure 5). The wedge-shaped Unit 2 is represented by sample DJFZ-OSL-20 (0.26 $\pm 0.06 \mathrm{ka} \mathrm{BP})$, which hints that the latest surface rupture faulting event should correspond to the CE 1738 great Danjiang earthquake.

In summary, the latest activity of the western segment along the DJF occurred after $0.68 \pm 0.10 \mathrm{ka} \mathrm{BP}$ and was closer to $0.26 \pm$ 0.06 ka BP, which most likely corresponds to the CE 1738 great historical earthquake. Field observations also reveal that there is little correspondence between the two sides of the fault zone, which implies that the kinematic properties of the fault are dominated by left-lateral motion. This observation is in good agreement with the above results of geomorphic investigations along the whole sections of the DJF (Figure 4).

\section{The Middle Segment of the DJF}

The middle ruptured segment of the DJF starts from Riqing village at its northwestern tip and terminates near Naidong village at its southeastern tip with a total length of $\sim 35 \mathrm{~km}$ (Figure $3 \mathrm{M}$ ). The co-seismic surface ruptures are revealed at eleven representative investigation sites, the locations of which are indicated in Figure $3 \mathrm{M}$.

The middle segment is highlighted by a linear fault trough, mole or extensional tracks, waterfalls, deflected gullies, offset ditches, and fault scarps that developed within unconsolidated alluvial and pluvial deposits, which duplicate a preexisting structural zone (Figure 6). Notably, the co-seismic displacements, both horizontal and vertical, along the middle segment are larger than those along the eastern and western segments.

Field geomorphologic observations in this segment show that the Quaternary unconsolidated sediments in the alluvialproluvial fans and river terraces are faulted and duplicate the preexisting structural zone (Figure 6A). Three modern gullies are vertically displaced by approximately $0.9 \pm 0.1 \mathrm{~m}$ but are horizontally deflected or offset by $\sim 3.5 \pm 0.1 \mathrm{~m}$ (Figures 6B-D). The height of the waterfall drops on the map is measured at $0.9 \pm 0.1 \mathrm{~m}$, which may represent the co-seismic vertical offset in the latest faulting event (Figures 6C-E). In addition, a series of fresh mole tracks is observed along the fault zone, and the average height of the fault troughs is measured at $\sim 2.1 \pm 0.1 \mathrm{~m}$ (Figure 6F). Although the lack of datable material makes it difficult to precisely determine the time of the last seismic event, the geomorphic features in Figure 6 may indicate that the fault slipped at the surface recently, which most likely resulted from the CE 1738 Dangjiang historical event.

During this segment, two trenches are excavated in the field to define the co-seismic deformation characteristics of the CE 1738 Dangjiang great event and the active tectonics of the DJF (Figures 7,8 ), and the sites of the trenches are marked in Figure $3 \mathrm{M}$.

One trench, located in the southwest corner of Riqing Village (Figure $3 \mathrm{M}$ ), is perpendicular to the general trend of the CE 1738 Dangjiang co-seismic surface rupture traces (Figure 7A). Field geomorphologic observations near this site show that the Quaternary unconsolidated sediments in the alluvial-proluvial fans and river terraces are faulted and duplicate the preexisting structural zone (Figure 7A). The youngest geomorphic surface is vertically offset by $1.0 \pm 0.2 \mathrm{~m}$, and this offset may correspond to the CE 1738 Dangiiang great earthquake (Figure 7A). The lateral 
TABLE 2 | Distribution of co-seismic displacements in CE 1738 Dangjiang earthquake.

\begin{tabular}{|c|c|c|c|c|c|c|}
\hline No & Latitude & Longitude & $L(m)$ & Marker & Brief description & References \\
\hline 1 & 33.701389 & 95.608420 & $1.5 \pm 0.1$ & Gully & The gully on the lower terrace $(\mathrm{T} 1)$ is sinistral offset of $\sim 1.5 \mathrm{~m}$ & This research \\
\hline 2 & 33.701539 & 95.624868 & $1.9 \pm 0.1$ & Small ditch & The modern ditch is deflected of $\sim 1.9 \mathrm{~m}$ & This research \\
\hline 3 & 33.700460 & 95.634369 & $2.3 \pm 0.1$ & Small ditch & The modern ditch is deflected of $\sim 2.3 \mathrm{~m}$ & This research \\
\hline 4 & 33.699114 & 95.644469 & $2.4 \pm 0.1$ & Small ditch & Small ditches on the piedmont alluvial fan are synchronized displaced of $\sim 2.4 \mathrm{~m}$ & This research \\
\hline 5 & 33.698314 & 95.650614 & $2.5 \pm 0.1$ & Small ditch & & This research \\
\hline 6 & 33.697348 & 95.655285 & $2.5 \pm 0.1$ & Small ditch & The ditch is deflected of $\sim 2.5 \mathrm{~m}$ while the older gully is abandoned (Figure $4 \mathbf{E}$ ) & This research \\
\hline 7 & 33.695716 & 95.662287 & $2.7 \pm 0.2$ & Gully & Gully on the lower terrace $(\mathrm{T} 1)$ is sinistral offset of $\sim 2.7 \mathrm{~m}$ & This research \\
\hline 8 & 33.688691 & 95.698120 & $2.9 \pm 0.2$ & Small ditch & The modern ditch is deflected of $\sim 2.9 \mathrm{~m}$ & This research \\
\hline 9 & 33.682455 & 95.737597 & $3.0 \pm 0.1$ & Small ditch & The modern ditch is deflected of $\sim 2.9 \mathrm{~m}$ & This research \\
\hline 10 & 33.660987 & 95.818018 & $3.0 \pm 0.1$ & Stone ridge & The stone ridges on the lower terrace $(\mathrm{T} 1)$ are sinistral offset of $\sim 3.0 \mathrm{~m}$ & This research \\
\hline 11 & 33.650396 & 95.847152 & $3.5 \pm 0.1$ & Small ditch & The modern ditch is deflected of $\sim 3.5 \mathrm{~m}$ (Figure 6B) & This research \\
\hline 12 & 33.648525 & 95.852919 & $3.5 \pm 0.1$ & Gully & Gully on the lower terrace (T1) is sinistral offset of $\sim 3.5 \mathrm{~m}$ (Figure $\mathbf{6 C}$ ) & This research \\
\hline 13 & 33.643550 & 95.875847 & $3.4 \pm 0.1$ & Gully & Gully on the lower terrace (T1) is sinistral offset of $\sim 3.4 \mathrm{~m}$ (Figure 6D) & This research \\
\hline 14 & 33.626890 & 95.931588 & $2.7 \pm 0.2$ & Small ditch & The modern ditch is deflected of $\sim 2.5 \mathrm{~m}$ & This research \\
\hline 15 & 33.605382 & 96.034834 & $1.5 \pm 0.1$ & Small ditch & Small ditches on the piedmont alluvial fan are synchronized sinistral offset & This research \\
\hline 16 & 33.596249 & 96.087238 & $1.0 \pm 0.1$ & Small ditch & The modern ditch is deflected of $\sim 1.0 \mathrm{~m}$ & This research \\
\hline 17 & 33.595581 & 96.103014 & $0.9 \pm 0.1$ & Small ditch & The modern ditch is deflected of $\sim 0.9 \mathrm{~m}$ (Figure $\mathbf{9 C}$ ) & This research \\
\hline 18 & 33.594679 & 96.108459 & $0.8 \pm 0.1$ & Gully & Gullies on the lower terrace (T1) are sinistral deflected of $\sim 0.8 \mathrm{~m}$ (Figure 9F) & This research \\
\hline 19 & 33.593837 & 96.127310 & $0.7 \pm 0.1$ & Small ditch & The modern ditch is deflected of $\sim 0.7 \mathrm{~m}$ & This research \\
\hline 20 & 33.587972 & 96.156238 & $0.5 \pm 0.1$ & Small ditch & The modern ditch is deflected of $\sim 0.5 \mathrm{~m}$ & This research \\
\hline 21 & 33.525030 & 96.356975 & 3.3 & Small ditch & Small ditches on the piedmont alluvial fan are synchronized sinistral offset & Wu et al. (2017) \\
\hline 22 & 33.525030 & 96.356975 & 4.5 & Small ditch & & \\
\hline 23 & 33.525030 & 96.356975 & 3.1 & Small ditch & & \\
\hline 24 & 33.529896 & 96.333975 & 4.0 & Gully & Gully depth of $0.5 \mathrm{~m}$ & Wu et al. (2017) \\
\hline 25 & 33.548903 & 96.277825 & 4.8 & Small ditch & & Wu et al. (2017) \\
\hline 26 & 33.556222 & 96.246250 & 4.8 & Gully & Gully is nearly perpendicular to the fault scarp which is about $1.5 \mathrm{~m}$ in height & Wu et al. (2017) \\
\hline 27 & 33.589904 & 96.158384 & 4.5 & Gully & Gully depth of $0.5 \mathrm{~m}$ is perpendicular to the fault scarp which is about $1.5 \mathrm{~m}$ in height & Wu et al. (2017) \\
\hline 28 & 33.594581 & 96.099504 & 4.9 & Gully & & Wu et al. (2017) \\
\hline 29 & 33.594139 & 96.094972 & 3.8 & Small ditch & & Wu et al. (2017) \\
\hline 30 & 33.594722 & 96.093944 & 3.5 & Gully & & Wu et al. (2017) \\
\hline 31 & 33.603722 & 96.043250 & 5.0 & Gully & Gully depth of $0.5 \mathrm{~m}$ & Wu et al. (2017) \\
\hline 32 & 33.604472 & 96.040083 & 5.0 & Gully & Gully depth of $0.5 \mathrm{~m}$ & Wu et al. (2017) \\
\hline 33 & 33.605650 & 96.034067 & 1.8 & Small ditch & Small ditch is nearly perpendicular to the fault scarp which is about $1.5 \mathrm{~m}$ in height & Wu et al. (2017) \\
\hline 34 & 33.618815 & 95.966376 & 3.6 & Gully & & Wu et al. (2017) \\
\hline 35 & 33.634833 & 95.907717 & 3.0 & Gully & Little yellow flower distribute along the small ditch & Wu et al. (2017) \\
\hline 36 & 33.635150 & 95.906833 & 5.0 & Gully & Cumulative displacement of two deformation events? & Wu et al. (2017) \\
\hline 37 & 33.650345 & 95.846409 & 4.6 & Gully & Gully on the lower terrace (T1) is sinistral offset of $5.0 \mathrm{~m}$ & Wu et al. (2017) \\
\hline 38 & 33.664119 & 95.803319 & 5.0 & Gully & Cumulative displacement of two deformation events? & Wu et al. (2017) \\
\hline 39 & 33.689267 & 95.692783 & 3.4 & Gully & Gully is nearly perpendicular to the fault scarp which is about $1.0 \mathrm{~m}$ in height & Wu et al. (2017) \\
\hline 40 & 33.697333 & 95.655194 & 3.5 & Gully & $\begin{array}{l}\text { Gullies are sinistral offset of } 3.5 \mathrm{~m}, 11 \mathrm{~m} \text { and } 24 \mathrm{~m} \text {, respectively; the offset of } 11 \mathrm{~m} \text { and } 24 \mathrm{~m} \\
\text { are cumulative offsets based on the field observations }\end{array}$ & Wu et al. (2017) \\
\hline 41 & 33.700333 & 95.634250 & 5.0 & Gully & Gully depth of $0.5 \mathrm{~m}$ & Wu et al. (2017) \\
\hline 42 & 33.726278 & 95.507528 & 4.8 & Gully & Gully is nearly perpendicular to the fault scarp which is about $0.5 \mathrm{~m}$ in height & Wu et al. (2017) \\
\hline 43 & 33.826678 & 95.239822 & 5.0 & Gully & Cumulative displacement of two deformation events? & Wu et al. (2017) \\
\hline 44 & 33.693888 & 95.670555 & 1.7 & Stone ridge & & (Li et al., 2016) \\
\hline 45 & 33.644444 & 95.875833 & 1.3 & Gully & The lower floodplain of gully (TO) are sinistral offset of $1.3 \mathrm{~m}$ & (Li et al., 2016) \\
\hline 46 & 33.611111 & 96.000833 & 1.7 & Gully & The higher floodplain of gully (T0) are sinistral offset of $1.7 \mathrm{~m}$ & (Li et al., 2016) \\
\hline 47 & 33.608333 & 96.015555 & 1.7 & Small ditch & Small ditch is sinistral offset of $1.7 \mathrm{~m}$ & (Li et al., 2016) \\
\hline 48 & 33.608333 & 96.015000 & 1.4 & Small ditch & Small ditch is sinistral offset of $1.4 \mathrm{~m}$ & (Li et al., 2016) \\
\hline 49 & 33.608055 & 96.018055 & 1.7 & Small ditch & Small ditch is sinistral offset of $1.7 \mathrm{~m}$ & (Li et al., 2016) \\
\hline 50 & 33.595000 & 96.094444 & 2.0 & Small ditch & Small ditch is sinistral offset of $2.0 \mathrm{~m}$ & (Li et al., 2016) \\
\hline 51 & 33.594722 & 96.095277 & 2.1 & Small ditch & Small ditch is sinistral offset of $2.1 \mathrm{~m}$ & (Li et al., 2016) \\
\hline
\end{tabular}

wall profile of the modern gully cleaned by manual work in the field shows the latest active characteristics of the fault (Figure 7B). Three units can be identified based on the main differences in the material composition and structures. Unit 1 , rich in plant roots, is a set of loose gray-brown sandy soils with a thickness of $\sim 20 \mathrm{~cm}$. Unit 2 is bluish-gray laminated gravel with more medium sand traps with a thickness of $\sim 40 \mathrm{~cm}$. Although the top of Unit 2 is generally intact, the bottom of the unit obviously suffers from deformation. Unit 3 , as the main deformed stratigraphic unit in the trench, is mainly composed of reddishbrown medium coarse sand with pebbles with a thickness of $\sim 80 \mathrm{~cm}$.

The fault traces F1-1, F1-2, F2-1, and F2-2 are sketched and recognized based on the formation occurrences and cross-cutting relationships between the stratigraphic units observed in the field (Figure 7B). Both faults cut the sediments of Units 2,3 and are 
overlain by Unit 1, and the accumulated offset of the faults is $\sim 0.5 \mathrm{~m}$. The gravel in the fault zone is well oriented (Figures 7C,D).

Three effective chronological data constrict the time of the latest deformation of these faults (Figure 7B). One $14^{\circ} \mathrm{C}$ dating result (DJFZ- ${ }^{14} \mathrm{C}-10$ ) tested by the Beta Laboratory in the United States reveals that formation three in the trench was formed in the late Holocene $(\sim 1,270 \pm 30 \mathrm{BP})$, and two OSL dating results further constrain that the latest deformation time of the fault is between $0.33 \pm 0.05 \mathrm{ka} \mathrm{BP}$ (DJFZOSL-22) and $0.46 \pm$ $0.03 \mathrm{ka} \mathrm{BP}$ (DJFZOSL-50). The dating results of these samples are in good agreement with the surface microgeomorphic deformation characteristics mentioned above, indicating that the latest tectonic deformation was formed during the $\mathrm{CE}$ 1738 Dangjiang historical earthquake.

Another trench was located on the southwest bank of the Dangjiang River (Figure $3 \mathrm{M}$ ). Field geomorphologic observations near this site show that the river terraces faulted and duplicated the preexisting structural zone (Figure 8A). The trench in terrace T2 is approximately $15 \mathrm{~m}$ long and $\sim 5 \mathrm{~m}$ high and is also perpendicular to the general trend of the CE 1738 Dangjiang co-seismic surface ruptures (Figure 8).

Enlarged maps of the trench wall reveal that the strata mainly consist of alluvial-diluvial material with obvious bedding and grinding features (Figures 8B,C). According to the differences of these alluvial-diluvial materials in structure and composition, four distinct units can be recognized. Unit 1, rich in plant roots, is mainly a set of dark-brown fine sand and loess with a thickness of approximately $10 \mathrm{~cm}$. Unit 2 is mainly a set of pale yellow sandy clays with an average thickness of $\sim 1.0 \mathrm{~m}$, the bottom of which is displaced by the faults. Unit 3 is a bluish gray pebble interbedded with medium coarse sand, with an average thickness of approximately $1.2 \mathrm{~m}$. Unit 4 is a reddish-brown sandy with obvious bedding and gravels, with a visible thickness of approximately $1.5 \mathrm{~m}$.

Three faults can be identified in the wall. Fault F1 vertically cuts Formation 2, Formation 3, and Formation four systematically, and its placement is $\sim 0.5 \mathrm{~m}$. Faults F2, and F3 have similar tectonic features, both of which cut the sediments of Units $4-2$ and are overlain by Unit 1 , the total displacements of which are $\sim 0.4 \mathrm{~m}$. Herein, it is speculated that the co-seismic vertical displacement of the CE 1738 Dangjiang historical earthquake was absorbed simultaneously by these three faults, and thus that the offset of $\sim 0.9$ m observed in the profile may represent the vertical offset during the CE 1738 Dangjiang historical earthquake.

Three chronological samples are collected at this point to constrain the recent deformation of the structure. The dating test result of sample DJFZOSL- 01 hints that the age of Unit 1 is $1.10 \pm 0.09 \mathrm{ka} \mathrm{BP}$. Two other data points, DJFZOSL-22 $(0.33 \pm$ $0.05 \mathrm{ka} \mathrm{BP})$ and DJFZ- ${ }^{14} \mathrm{C}-04(770 \pm 30 \mathrm{BP})$, in Unit 2 further constrain the latest activity time of the DJF. All these results hint that the latest rupture should have occurred in the CE 1738 Dangjiang historical earthquake with a co-seismic vertical offset of $\sim 0.9 \mathrm{~m}$.

In brief, the latest activity of the middle segment along the DJF occurred after $770 \pm 30 \mathrm{BP}$ and was closer to $0.33 \pm 0.05 \mathrm{ka} \mathrm{BP}$, which most likely corresponds to the CE 1738 great historical earthquake. Tectonic geomorphic features and interpretation of trench results hint that the kinematic properties of the fault are dominated by left-lateral motion.

\section{The Eastern Segment of the DJF}

The $\sim 35 \mathrm{~km}$-long eastern ruptured segment of the DJF starts from Chanaka village at its northwestern end and stops near the Jielong River at its southeastern end (Figure $3 \mathrm{E}$ ). The co-seismic surface ruptures in the CE 1738 Dangjiang great earthquake are delineated by six representative observation points, the locations of which are marked in Figure 3 E.

Although the geomorphic characteristics of strike-slip movement, such as consistently deflected gullies and fault saddles along the structure, are still as abundant as those of the western and middle sections, the co-seismic displacements in the eastern segment sharply decrease (Figure 9). Field observations reveal that Paleogene brown-red sandstone with gravel is over thrusted by Triassic gray-black sandstone. Recent fault activity ruptured the surficial Quaternary yellow-brown soil by thrusting, above which $\sim 0.8 \pm 0.1 \mathrm{~m}$ co-seismic vertical offsets can be observed (Figure 9A). Several modern creeks and gully terraces are deflected or offset by the movement of the structure, and the horizontal displacement decreases from $1.5 \pm 0.1 \mathrm{~m}$ near Chanaka village to $0.5 \pm 0.1 \mathrm{~m}$ in Dongduola village and then disappears just across the Jielong River; meanwhile, the vertical displacements also decrease from $\sim 0.9 \pm 0.1 \mathrm{~m}$ east of Lixin town to $\sim 0.3 \pm 0.1 \mathrm{~m}$ on the east bank of the Jielong River and then gradually fade away.

\section{DISCUSSION}

\section{Co-Seismic Surface Ruptures Produced by the CE 1738 Dangjiang Earthquake}

It is widely accepted that co-seismic surface ruptures resulting from great earthquakes are crucial for understanding the activity habits of seismogenic faults. Thus, the first goal in the discussion is to decipher the deformation characteristics of the DJF through the co-seismic surface ruptures produced by the CE 1738 Dangjiang earthquake. According to the observed deformation features of the sedimentary layers, the fault structures, and the dating of samples in this research, a nearly $100 \mathrm{~km}$-long coseismic surface rupture zone associated with the CE 1738 Dangjiang historical earthquake is proposed here (Figure 2). The rupture zone is interpreted as a nearly straight lineament trending E-W to WNW-ESE in the satellite images that were used for field mapping and investigation (Figures 2, 3). The surface ruptures are concentrated in a zone with average widths of 5-35 m. The surface fault zone constitutes distinct shear faults, consistent offset or deflected gullies, linear scarps, fault troughs, sag ponds, mole tracks, and depressions, most of which are distributed along the fault lineament, as shown in the satellite image (Figures 2, 3).

The distribution of the co-seismic displacements from the $\mathrm{CE}$ 1738 Dangjiang earthquake is further measured based on satellite images and field verification (Figure 10), and all displacements are measured along the co-seismic rupture zone via displaced linear geomorphic and geologic markers such as fault scarps, 
TABLE 3 | Estimated Holocene slip rates of the typical observation sites along the DFZ.

\begin{tabular}{|c|c|c|c|c|}
\hline Observation sites & Morphologic units & Results of chronology & $\begin{array}{c}\text { Measured } \\
\text { horizontal displacements }\end{array}$ & Estimated slip rate \\
\hline Dasheng village (Figure 11) & T2 terrace & $\begin{array}{l}3.04 \pm 0.37 \text { ka BP } \\
\text { (Wu et al., 2017) }\end{array}$ & $\begin{array}{l}29.0 \pm 1.0 \mathrm{~m}(\mathrm{Wu} \text { et } \mathrm{al} ., 2017) \\
28.0 \pm 1.0 \mathrm{~m}\end{array}$ & $\begin{array}{c}7 \pm 3 \mathrm{~mm} / \mathrm{yr}(\text { Wu et al., 2017) } \\
9.2 \pm 1.1 \mathrm{~mm} / \mathrm{yr}\end{array}$ \\
\hline West of the Riqing Village (Figure 12) & $\begin{array}{l}\text { T1 terrace } \\
\text { T2 terrace } \\
\text { T3 terrace }\end{array}$ & $\begin{array}{c}3.38 \pm 0.03 \mathrm{ka} \mathrm{BP} \\
3.76 \pm 0.20 \mathrm{ka} \mathrm{BP} \\
10.47 \pm 0.58 \mathrm{ka} \mathrm{BP}\end{array}$ & $\begin{array}{l}23.0 \pm 0.2 \mathrm{~m} \\
28.0 \pm 0.5 \mathrm{~m} \\
73.0 \pm 2.0 \mathrm{~m}\end{array}$ & $\begin{array}{l}6.8 \pm 0.1 \mathrm{~mm} / \mathrm{yr} \\
7.4 \pm 0.4 \mathrm{~mm} / \mathrm{yr} \\
6.9 \pm 0.4 \mathrm{~mm} / \mathrm{yr}\end{array}$ \\
\hline South of the Riqing Village (Figure 13) & $\begin{array}{l}\text { T2 terrace } \\
\text { T1 terrace }\end{array}$ & $\begin{array}{l}3.08 \pm 0.50 \mathrm{ka} \mathrm{BP} \\
2.44 \pm 0.14 \mathrm{ka} \mathrm{BP}\end{array}$ & $\begin{array}{l}26.0 \pm 0.5 \mathrm{~m} \\
20.0 \pm 0.2 \mathrm{~m}\end{array}$ & $\begin{array}{l}8.4 \pm 1.4 \mathrm{~mm} / \mathrm{yr} \\
8.2 \pm 0.5 \mathrm{~mm} / \mathrm{yr}\end{array}$ \\
\hline $\begin{array}{l}\text { South of Dangjiang (Wu et al., 2017) } \\
\text { Near the Dangjiang village (Zhou et al., 1997) }\end{array}$ & $\begin{array}{l}\text { T3 terrace } \\
\text { T2 terrace }\end{array}$ & $\begin{array}{l}9.88 \pm 1.88 \mathrm{ka} \mathrm{BP} \\
5.8 \pm 0.20 \mathrm{ka} \mathrm{BP}\end{array}$ & $\begin{array}{c}70 \pm 10 \mathrm{~m} \\
42.0 \pm 5.0 \mathrm{~m}\end{array}$ & $\begin{array}{l}7.1 \pm 1.6 \mathrm{~mm} / \mathrm{yr} \\
7.2 \pm 0.8 \mathrm{~mm} / \mathrm{yr}\end{array}$ \\
\hline
\end{tabular}

TABLE 4 | Summarized activity parameters of the GYFZ in Holocene.

\begin{tabular}{|c|c|c|c|c|c|c|}
\hline Segmentation & Ganzi S & Manigange S & Dengke S & Yushu S & Dangjiang S & References \\
\hline Estimated magnitude of historical earthquake & $1845 \mathrm{Ms} 7.3$ & $\begin{array}{c}1854 \mathrm{Ms} 7.7 \\
1854 \mathrm{Mw} 7.7 \\
\\
180\end{array}$ & $\begin{array}{l}1896 \mathrm{Ms} 7.5 \\
1896 \mathrm{Ms} 7.3\end{array}$ & 2010 Ms 7.1 & $\begin{array}{c}1738 \mathrm{Ms} 7.3 \\
1738 \mathrm{Mw} 6.8-7.2 \\
1738 \mathrm{Ms} 7.3 \\
1738 \mathrm{Mw} 7.5 \\
1738 \mathrm{Ms} 7.6\end{array}$ & $\begin{array}{l}\text { Zhou et al. (1997) } \\
\text { Wen et al. (2003) } \\
\text { Chen et al. (2010) } \\
\text { Wu et al. (2017) } \\
\text { (Li et al., 2016) } \\
\text { (Li et al., 2016) } \\
\text { This research } \\
\text { Wen et al. (2003) } \\
\text { Chen et al. (2010) } \\
\text { Li et al. (2012) }\end{array}$ \\
\hline Co-seismic surface rupture length $(\mathrm{km})$ & $\begin{array}{l}3.4 \pm 0.3 \\
11.5 \pm 2.4 \\
14.3 \pm 3\end{array}$ & $\begin{array}{c}7.0 \pm 0.7 \\
3.3-5.0 \\
12.8 \pm 1.7 \\
13.4 \pm 2\end{array}$ & $\begin{array}{l}7.2 \pm 1.2 \\
11.3 \pm 1.8\end{array}$ & & $\begin{array}{c}\quad 85 \\
\sim 100 \\
\\
7.3 \pm 0.6 \\
\sim 7.3\end{array}$ & $\begin{array}{l}\text { (Li et al., 2016) } \\
\text { Wu et al. (2017) } \\
\text { This research } \\
\text { Zhou et al. (1996) } \\
\text { Li et al., 1995 } \\
\text { Wen et al. (2003) } \\
\text { Xu et al. (2003a) }\end{array}$ \\
\hline Average horizontal co-seismic offset $(\mathrm{m})$ & $1.7 \pm 0.2$ & $4.3 \pm 0.6$ & $2.6 \pm 0.3$ & $\begin{array}{c}2.6 \pm 0.3 \\
0.5-1\end{array}$ & $\begin{array}{c}1.7 \\
2.1 \pm 0.1\end{array}$ & $\begin{array}{l}\text { Zhou et al. (1997) } \\
\text { Li et al. (2012) } \\
\text { (Li et al., 2016) } \\
\text { This research }\end{array}$ \\
\hline Average repeated time of great earthquakes (a) & $500 \pm 74$ & $\begin{array}{c}614 \pm 105 \\
667 \pm 61\end{array}$ & $\begin{array}{l}361 \pm 73 \\
443 \pm 67\end{array}$ & $500 \pm 74$ & $\begin{array}{l}356 \pm 41 \\
274 \pm 30\end{array}$ & $\begin{array}{l}\text { Zhou et al. (1997) } \\
\text { Chen et al. (2010) }\end{array}$ \\
\hline
\end{tabular}

stream channels, gullies, and terraces, which generally intersect the surface rupture zone vertically (Table 2 ). Along the $\sim 100 \mathrm{~km}$ long surface rupture zone, the co-seismic displacements at 20 locations are jointly measured by a laser rangefinder, a steel tape, and a drone. We also collected and verified data from 31 previous surveys (Table 2, Zhou et al.,1997; Li et al., 2016; Wu et al., 2017). What needs to be pointed out is that the coexistence of nearly double-magnitude offsets in the gullies (e.g., displacements measured in No. 37 and No. 40 in Table 2 and the observation site in Figure 4E) at the same site hints that the structure might have experienced multiple stages of repeated sliding along the pre-existing fault line, and the minimum displacement is regarded as the co-seismic offset of the CE 1738 Dangjiang earthquake. Finally, 20 field survey data points were fitted and then compared with previous studies (Figure 10).

The statistical data show that the in situ co-seismic offsets owing to the CE 1738 Dangjiang earthquake are left-lateral and vary from 1.0 to $3.5 \mathrm{~m}$ horizontally, and the average and maximum left-lateral slip displacements are $\sim 2.1 \pm 0.1 \mathrm{~m}$ and $\sim 3.5 \pm 0.1 \mathrm{~m}$, respectively (Figure 10). The maximum and average vertical displacements of the CE 1738 Dangjiang earthquake were 1.0 and $0.3 \mathrm{~m}$, respectively (Figure 10). The fitted figure also shows that the maximum horizontal 
displacements are mainly concentrated in the central part of the fault sections, such as at Riqing village, Lixin town, and Naidong village (Figure 10), while they sharply decrease toward the fault ends in Dangjiangrong village and the Jielong River, respectively. This particular statistical figure almost approaches that of the schematic illustration of an ideal, isolated earthquake (Figure 10), where the displacement profile indicates the maximum offset near the structural center and decreases toward the fault tips (Fossen, 2016). Although the variation gradient of the fitted coseismic vertical displacement distribution is not as dramatic as that of the horizontal displacement, its overall spatial distribution shows a decreasing trend from the middle toward the ends (Figure 10).

Our field investigation did not extend into the area west of Duocai village because there are no interpreted surface traces of the CE 1738 Dangjiang co-seismic deformation in the remote sensing images (Figure 2) and because this area is too difficult to access given high and steep mountains, seasonal glaciers, permanent marshes, and inconvenient transportation. If the co-seismic rupture of the earthquake did not spread to the area west of Duocai village, this asymmetrical co-seismic distribution may mean that the co-seismic rupture process of the CE 1738 Dangjiang earthquake might start from Duocai village, propagate unilaterally eastward, and finally terminate in the vicinity of the Jielong River. In fact, previous studies have shown that the 2010 Yushu earthquake has similar unilateral propagation characteristics (Li et al., 2012). Herein, it is thus proposed that the surface rupture of the CE 1738 Dangjiang earthquake may be $\sim 100 \mathrm{~km}$ long (Figure 2), which is slightly different from previous studies (Institute of Geophysics, China Seismological Bureau, 1990; Zhou et al., 1997; Chen et al., 2010; Yin, 2011).

\section{Magnitude Estimation of the CE 1738 Dangjiang Earthquake}

The magnitude of the CE 1738 Dangjiang earthquake is reestimated based on the newly observed parameters described above. Previously, scientists have suggested that the magnitude estimation is jointly influenced by the co-seismic surface-rupture length and the maximum displacement observed on a continental fault trace (Deng et al., 1992; Wells and Coppersmith, 1994; McCalpin, 2009) and that there are no obvious surface ruptures if the magnitude is smaller than $M 6.5$ on the Tibetan Plateau (Deng et al., 1992; Yin, 2011). Furthermore, based on more than 60 detailed modern surface-rupture earthquakes distributed in different tectonic regions that exhibit different tectonic features in the East Asia area, Deng et al. (1992) presented different kinds of distinctive fitted functions between the magnitude of an earthquake $(M)$, the length of the surface rupture (L), and the maximum displacement (D). Herein, the following fitted function is adopted according to their research (Eq. 1):

$$
\mathrm{M}=6.34+0.49 \lg (\mathrm{LD})
$$

$\mathrm{M}$ : the estimated magnitude of the earthquake;

L: the length of the co-seismic surface ruptures in kilometers;

$\mathrm{D}$ : the maximum displacements in meters.
In the above equation, $\mathrm{L}$ stands for the length of the surface rupture, which is assigned a value of $100 \mathrm{~km}$ in this study according to the satellite image interpretation and field observations. Here, D refers to the maximum horizontal displacement of a single event, which is assigned a value of $3.5 \mathrm{~m}$. As a result, the magnitude of the CE 1738 Dangjiang earthquake can be estimated as $M 7.6$ based on the co-seismic surface rupture length and the maximum displacement observed in the field. (Deng et al., 1992).

If we use the calculation formula suggested by Wells and Coppersmiths (1994, Eq. 2), the calculation result is $M 7.4$ based on the $\sim 100 \mathrm{~km}$ long co-seismic surface rupture length. (Wells and Coppersmiths, 1994).

$$
\mathrm{M}=5.16+1.12 \lg (\mathrm{L})
$$

In general, the estimated magnitude of $M 7.6$ is basically consistent with those of previous studies. Although the traffic and living conditions on the Tibetan Plateau were inconvenient in earlier years and thus would have directly affected field observations, many scientists attempted to estimate the likely magnitude of this great historical earthquake based on geological surveys and historical documents. For example, Zhou et al. (1997) suggested that the possible magnitude of this great historical earthquake was $\sim M 7.5$ based on an average left-lateral displacement of $\sim 5 \mathrm{~m}$, while Chen et al. (2010) estimated a magnitude of $\sim M 7.1$ according to a co-seismic surface strikeslip displacement of $\sim 2 \mathrm{~m}$ and a co-seismic surface rupture length of $\sim 31 \mathrm{~km}$. Lin et al. (2011), based on a comparative study with the 2010 Ms 7.1 Yushu earthquake proposed that the minimum magnitude of the CE 1738 Dangjiang earthquake was Ms 6.5 and that the magnitude was probably less than $M$ s 7.3 or perhaps $M$ s 7.1 , with a co-seismic offset of $\sim 1.5-2.0 \mathrm{~m}$. Other scientists speculated that the co-seismic rupture of the CE 1738 Dangjiang great earthquake might have propagated into the Yushu segment of the Ganzi-Yushu Fault Zone (Zhou et al., 1997; Lin et al., 2011) and that the surface rupture length in the CE 1738 Dangjiang earthquake may have reached or exceeded $130 \mathrm{~km}$ with an estimated magnitude of $7 \frac{1}{2}$ based on a review of historical records (Yuan et al., 2011). All these results mean a larger magnitude than the previously suggested size of 6.5 or $61 \frac{1}{2}$ (Institute of Geophysics, China Seismological Bureau, 1990). In addition, the chronological results obtained in recent years may be more reliable than older results if the advances in testing technology over the last 20 years are taken into account. In fact, both historical record research and field geological survey results support that the $\sim 100 \mathrm{~km}$ co-seismic rupture length is approximately representative of the $\mathrm{M}=7.5+$ earthquake along the GYFZ (Table 4). Thus, it is proposed that the magnitude of the CE 1738 Dangjiang earthquake most likely was $M 7.6$, with a co-seismic surface rupture of $\sim 100 \mathrm{~km}$ in length, and that the average and maximum strike-slip displacements are $\sim 2.1 \pm 0.1 \mathrm{~m}$ and $\sim 3.5 \pm 0.1 \mathrm{~m}$, respectively.

\section{Active Tectonics of the DJF}

Field observations reveal that the DJF is an active structure that has been undergoing repeated left-lateral strike-slip motion 

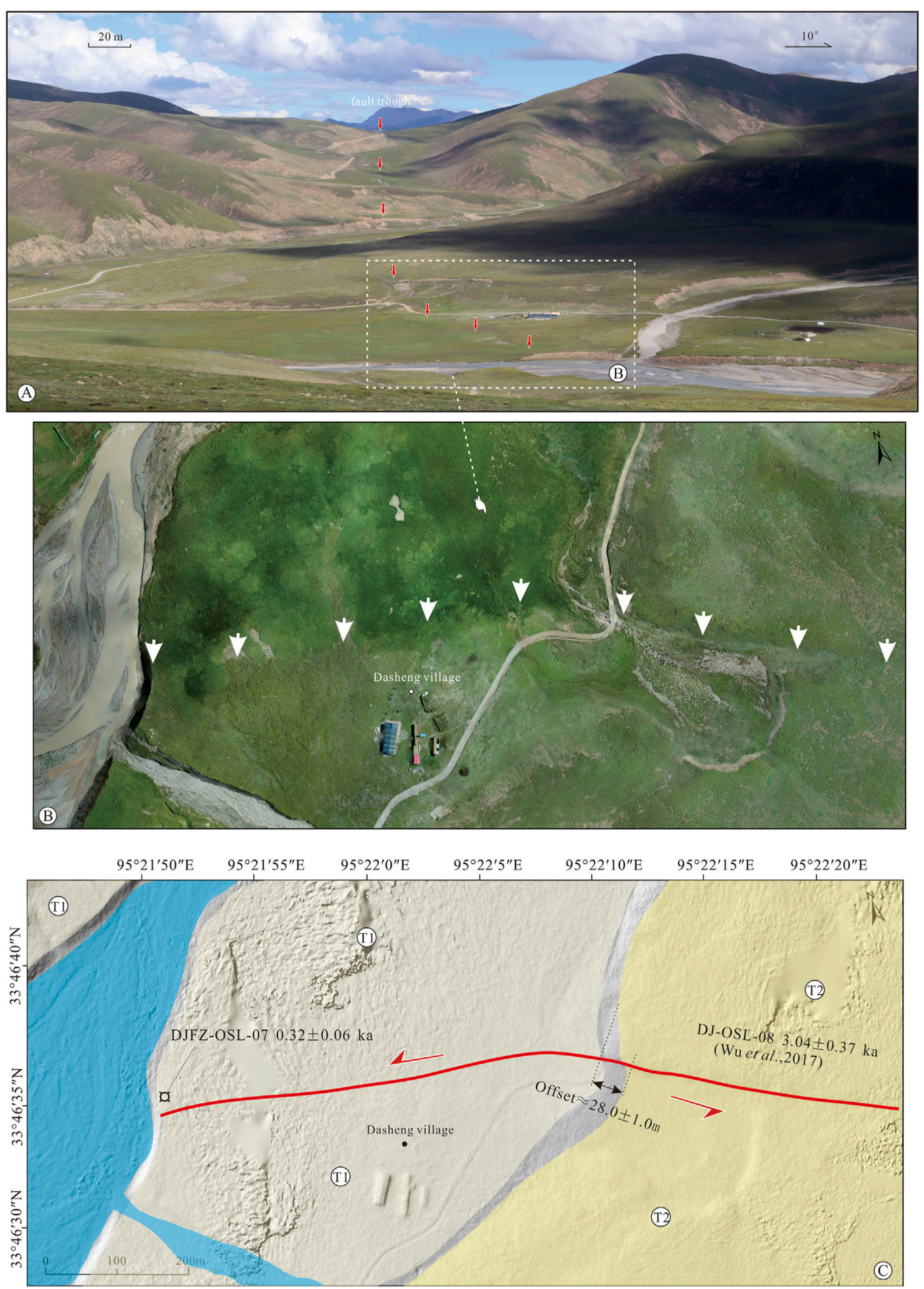

FIGURE 11 | Tectonic geomorphic features in Dasheng village along the western section of the DJF (the study site is marked in Figure $\mathbf{3}$ W). (A) Fault activity formed distinct troughs and valleys, and the red arrows in the map delineate the fault trace. (B) The orthophoto image taken from a drone shows that river terraces T1 and T2 are displaced by the activity of the DJF. (C) Interpreted map and field investigation further reveal that the horizontal displacements of terrace T2 are $\sim 28.0 \pm 1.0 \mathrm{~m}$. 



FIGURE 12 | Tectonic geomorphic features west of Riqing village along the middle section of the DJF (the study site is marked in Figure $\mathbf{3}$ M). (A) The orthophoto image taken from a drone shows that the fault activity displaced the gully and river terraces, and the white arrows in the map delineate the fault trace. (B) Interpreted map and field investigation hint that the horizontal displacements of terraces T1, T2, and T3 are $\sim 23.0 \pm 0.2 \mathrm{~m}, 28.0 \pm 0.5 \mathrm{~m}$, and $73.0 \pm 2.0 \mathrm{~m}$, respectively. Red lines in the map represent the surface rupture traces.

during the late Quaternary. Although trenches reveal normal features that conflict with the patterns of geomorphic scarps (Figures 5, 7, 8) because of the so-called "dolphin effect" along the strike-slip fault or of the gravity collapse of the main fault at the surface, the overall kinematic property of the fault should be left-lateral strike-slip, and there will be deformation of normal and reverse faults in local areas or observation sites. The above inferences are further proven by the following observations at different points along the DJF. In general, the older and larger geomorphic and geologic markers, such as stream channels and terraces, across the DJF structure display greater offsets than younger and smaller markers (Figures 4-9). For example, a gully is offset by a preexisting fault, and the co-seismic surface rupture from the CE $1738 M 7.6$ Dangjiang historical earthquake, with an accumulated horizontal displacement of $\sim 9.4 \pm 0.4 \mathrm{~m}$ and an accumulated vertical displacement of $\sim 3.0 \pm$ $0.2 \mathrm{~m}$ (Figure 4B). An abandoned gully with an accumulated horizontal displacement of $5.1 \pm 0.2 \mathrm{~m}$ shows that the fault may have experienced two left-lateral strike-slip movements if the co-seismic displacement in the latest faulting event is estimated at $\sim 2.5 \pm 0.1 \mathrm{~m}$ (Figure 4E). Similar cumulative displacement distributions are also well verified by the deformation characteristics on the stream terraces, which show that the displacements of old stream terraces are much greater than those 

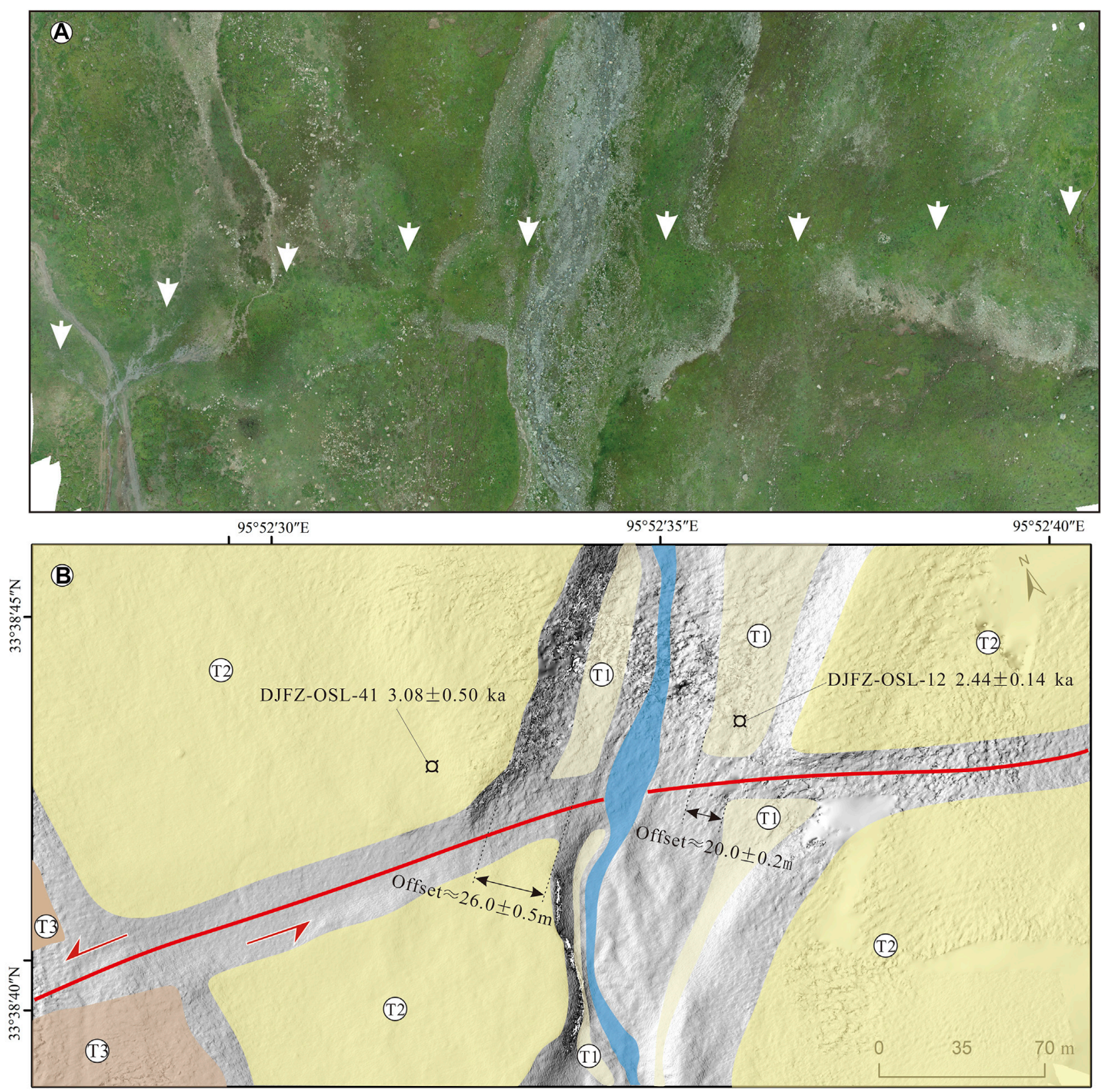

FIGURE 13 | Tectonic geomorphic features south of Riqing village in the middle section of the DJF (the study site is marked in Figure $\mathbf{3}$ M). (A) The orthophoto image taken from a drone shows that the fault activity displaced the gully and terraces, and the white arrows in the map delineate the fault trace. (B) Interpreted map and field investigation hint that the horizontal displacements of terraces T1 and T2 are $20.0 \pm 0.2 \mathrm{~m}$ and $26.0 \pm 0.5 \mathrm{~m}$, respectively. The red lines in the map represent the surface-rupture traces.

of young stream terraces. For example, three regional rivers of different sizes that flow through the research area, named the Zhiduo River, Dangjiang River, and Jielong River from northwest to southeast, have obviously experienced long-term left-lateral strikeslip tectonic deformation with accumulated displacements of $\sim 6, \sim 16$, and $\sim 5 \mathrm{~km}$, respectively (Figures 2, 3) (Wang et al., 2007). These offsets indicate that the DJF has a long history of repeated activity. All these field observations and the accumulated displacements show that the DJF has experienced multiple repeated sinistral strike-slip seismic slips.

The estimation of slip rates reveals that this repeated activity is typical of the fault's long-term history. Previous studies show that the whole XFZ is sinistrally displaced at a slip rate of $15 \pm 5 \mathrm{~mm} / \mathrm{yr}$ in its northernmost section, decreasing to $\sim 5 \mathrm{~mm} / \mathrm{yr}$ in its southern section (Molnar and Deng, 1984; Tang et al., 1984; Allen et al., 1991; Wang 


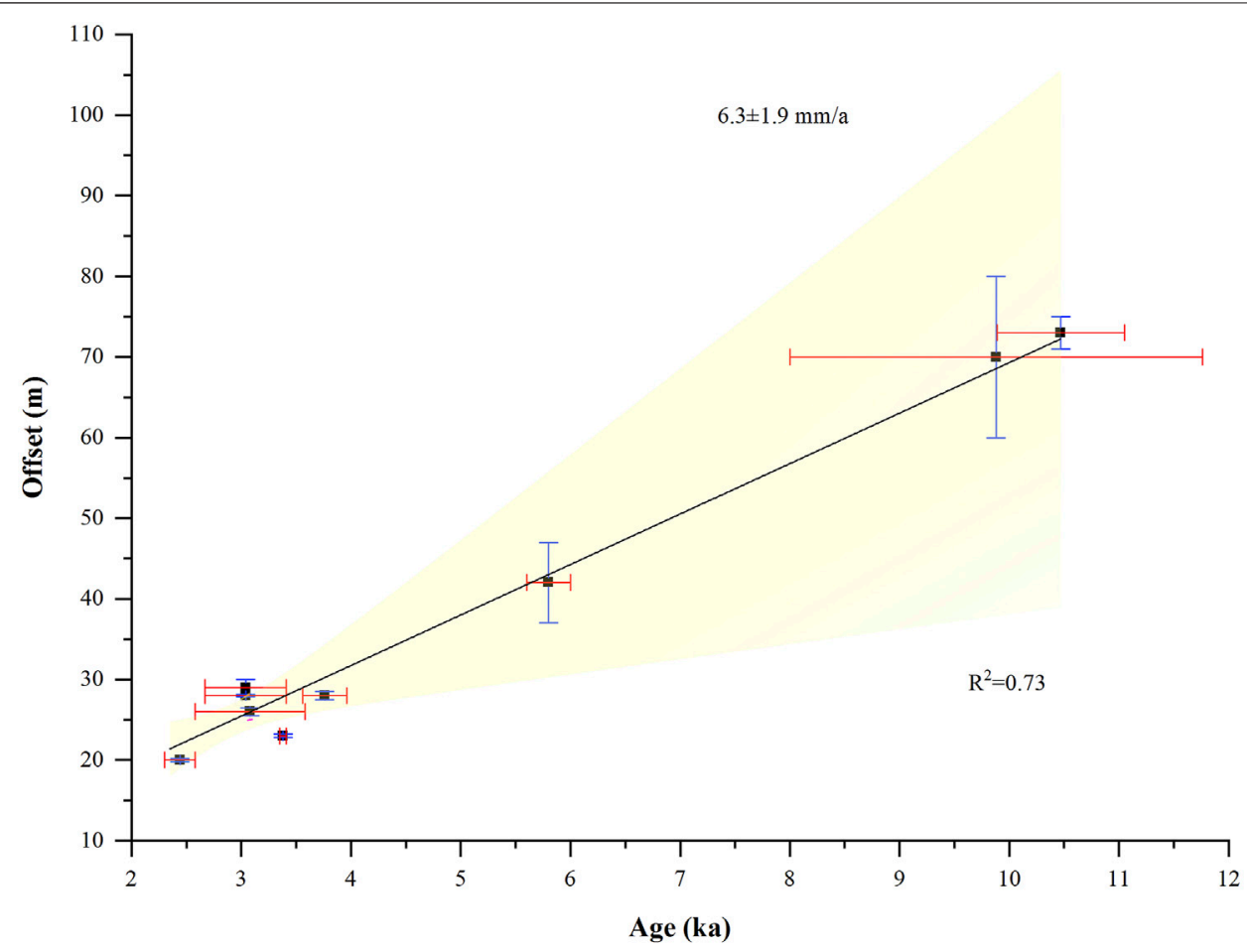

FIGURE 14 | Graph showing ages and offsets for individual sites along the DJF structure in the Holocene (Table 3). Blue and red error bars are the respective offsets and ages measured in the field. The linear fitting result with a 95\% confidence interval hints that the horizontal slip rate of the DJF in the Holocene is estimated at $6.3 \pm 1.9 \mathrm{~mm} / \mathrm{yr}$.

et al., 2001; Lin et al., 2002; Peng et al., 2006; Wang et al., 2007; Wang and Shen, 2020); the strike-slip rate estimations for the GYFZ section vary, including 3.4-7.3 $\mathrm{mm} / \mathrm{yr}$ (Zhou et al., 1997), $12 \mathrm{~mm} / \mathrm{yr}$ (Wen et al., 2003), $\sim 5 \mathrm{~mm} / \mathrm{yr}$ (Zhang et al., 2004), and $2-5 \mathrm{~mm} / \mathrm{yr}$ (Lin et al., 2011). These differences may mainly result from the dating methods used and the displacement of the geomorphic surface measured.

Herein, the horizontal slip rate along the DJF in the Holocene is estimated according to the different geomorphic surface exposure ages and the corresponding measured displacements from four typical observation sites (Table 3; Figures 11-13). The most typical survey site is located west of Riqing village in the middle part of the fault (Figure 12). The exposure ages of three geomorphologic surfaces, T3, T2, and T1, are well constrained by three dated samples, DJFZ-OSL-02 (10.47 $\pm 0.58 \mathrm{ka} \mathrm{BP})$, DJFZOSL-51 (3.76 $\pm 0.20 \mathrm{ka} \mathrm{BP})$, and DJFZ- ${ }^{14} \mathrm{C}-06(3.38 \pm 0.03 \mathrm{ka}$ $\mathrm{BP})$, and the left-lateral displacements are measured to be $73.0 \pm 2.0 \mathrm{~m}, 28.0 \pm 0.5 \mathrm{~m}$, and $23.0 \pm 0.2 \mathrm{~m}$, respectively (Figure 12). Thus, it is further estimated that the horizontal slip rate of the DJF near Dangjiang village is approximately $6.8 \pm 0.1-7.4 \pm 0.4 \mathrm{~mm} / \mathrm{yr}$. The same calculation method is applied to other observation sites (Figures 11, 13), and the estimated results are basically consistent (Table 3 ). The estimated slip rate of the western end of the fault
(Figure 11) is slightly larger than that in the middle segment of the fault (Figures 12, 13). There are two possible reasons for this tiny difference: errors in dating or displacement measurements and local erosion processes near the river. Additionally, Wu et al. (2017) suggested that the slip rate at this site (Figure 11) is approximately $7 \mathrm{~mm} / \mathrm{yr}$ if the formation time of the upper and lower terrace surfaces is jointly used to constrain the initial time of displacement. Therefore, the linear fitting surface displacement rate with a $95 \%$ confidence interval is $6.3 \pm 1.9 \mathrm{~mm} / \mathrm{yr}$ (Figure 14). Collectively, this surface displacement rate falls within the confidence intervals of earlier estimates (Molnar and Deng, 1984; Allen et al., 1991; Wen et al., 2003; Peng et al., 2006; Wang and Shen, 2020). Notably, the estimated slip rate of $6.3 \pm 1.9 \mathrm{~mm} / \mathrm{yr}$ is highly consistent with previous studies from GPS and INSAR observations (Wang et al., 2011; Liu et al., 2011).

\section{Implications for Seismic Hazard and Strain Partitioning Along the Southern Boundary of the Bayan Har Block in the Central Tibetan Plateau}

The spatial-temporal distribution of co-seismic ruptures during historical earthquakes is of great importance in assessing the seismic hazard presented by active faults. 

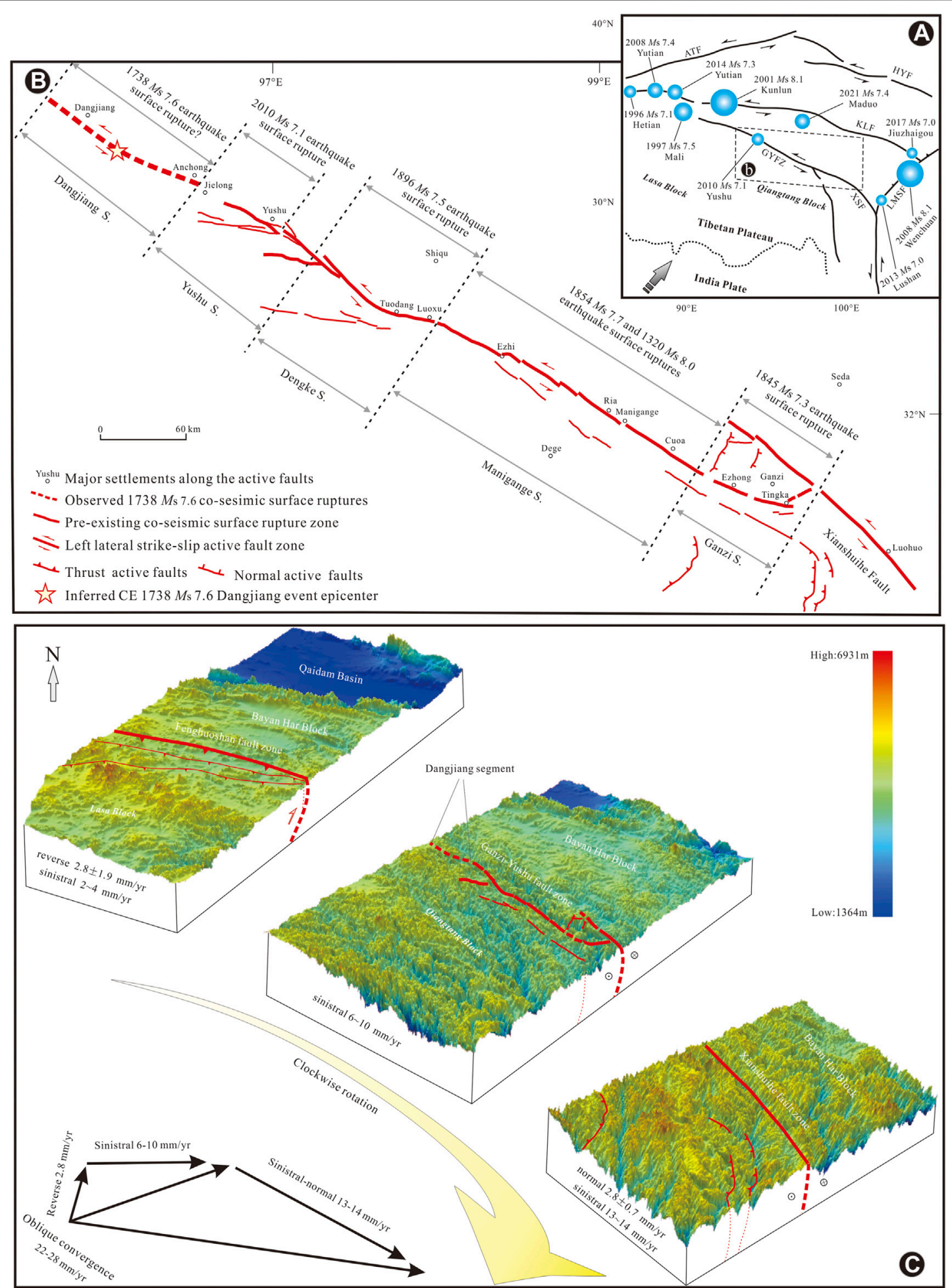

FIGURE 15 | Geometrics of the Ganzi-Yushu Fault Zone and the co-seismic surface ruptures resulting from historical great earthquakes along the northwestern continuation of the Xianshuihe Fault Zone (XFZ) in the high mountain area of the central Qinghai-Tibetan Plateau. (A) Index map showing the major active faults and great earthquakes around the Bayan Har Block boundary in the northern Qinghai-Tibet Plateau. ATF, Altyn Tagh Fault; HYF, Haiyuan Fault; KLF, Kunlun Fault; GYFZ, GanziYushu Fault Zone; LMSF, LongMenShan Fault Zone; XFZ, Xianshuihe Fault Zone, FFZ, Fenghuoshan Fault Zone. The gray-black arrow in the lower left corner approximately represents the direction of the northward subduction of the Indian Plate. (B) Sketch map showing the geometric distribution of the GYFZ and the coseismic surface ruptures resulting from historical great earthquakes along the structure. Dangjiang S, Dangjiang segment; Yushu S, Yushu segment; Dengke S, Dengke 
FIGURE 15 | segment; Manigange S, Manigange segment; Ganzi S, Ganzi segment (part of segments refer to Zhou et al., 1996; Zhou et al., 1997; Wen et al., 2003; Deng et al., 2007; Chen et al., 2010; Lin et al., 2011; Li et al., 2012). Traces of co-seismic surface rupture in the CE 1738 Ms 7.6 Dangjiang earthquake is delineated by a red dashed line based on satellite image interpretation and field investigation. (C) Cartoon model of the strain partition along the southern boundary of the Bayan Har Block. The base map of the digital elevation model is $90 \mathrm{~m}$ resolution SRTM (Shuttle Radar Topography Mission) data. Some faults and slip rates refer to previous studies (Zhou et al., 1996; Zhou et al., 1997; Wen et al., 2003; Deng et al., 2007; Chen et al., 2010; Wang et al., 2011; Lin et al., 2011; Li et al., 2012; Li et al., 2016; Wu et al., 2017). The cartoon map shows that the oblique convergence of the Qiangtang Block might be accommodated mainly by clockwise rotation through repeated left-lateral strike-slip movements along the southern boundary of the Bayan Har Block in the central Tibetan Plateau.

Previous studies show that at least ten strong earthquakes $(M s \geq 7)$ have occurred along the boundaries of the Bayan Har Block in the northern Qinghai-Tibetan Plateau (Figure 15A). These strong earthquakes hint that tectonic strain is mainly concentrated on the boundaries of the block, with minor deformation in the block interior (Thatcher, 2007; Michale and Yin, 2009). In particular, along the southern boundary of the block, the activity of the northwestern continuation of the XFZ has resulted in numerous destructive earthquakes in history, such as the CE 2010 Yushu Ms 7.1, the CE 1896 Dengke Ms 7.5, the CE 1845 Ms 7.3 in the Ganzi step, the CE 1738 Dangjiang Ms 7.6, the CE $1854 M s$ 7.7, and the CE $1320 \mathrm{Ms} 8.0$ in the Maligange area (Figure 15A). Although these great earthquakes have ruptured different segments of the GYFZ with variable co-seismic surface rupture sizes, activity parameters, and distinctive spatial-temporal distribution features (Figure 15B; Table 4, some co-seismic surface rupture distribution images are after Zhou et al., 1996; Zhou et al., 1997; Wen et al., 2003; Deng et al., 2007; Chen et al., 2010; Lin et al., 2011), previous studies suggest that the tectonic deformation along most sections of the XFZ is indeed consistent with the characteristic earthquake model. Thus, this spatial-temporal distribution of co-seismic ruptures may indicate that the recurrence probability of a strong earthquake along the Dangjiang segment cannot be underestimated given that its $\sim 283$ years elapsed time of the last great faulting event is basically close to the $\sim 350 \pm 41$ years recurrence interval of major earthquakes (Table 4; Zhou et al., 1997) or even slightly beyond its recurrence cycle of $\sim 274 \pm 30$ years (Table 4; Chen et al., 2010).

Our study area is located in a transitional area between the Tibetan Plateau to the west and its southeastern margin to the southeast, and the latter area experienced clockwise rotation around the northeastern syntaxis of the Himalayas with a component of southeastward extrusion (Wang et al., 2008). The strain partition in this area is crucial for understanding the southeastward extrusion process. Previous studies indicate that multiple repeated sinistral strike-slip movements along the boundary fault may accommodate the convergent motion of the block. However, how can the strain distribution process be quantitatively understood? This question has important implications for the tectonic deformation of the central region of the Qinghai-Tibet Plateau. The study of the kinematics of the boundary belt is helpful to answer this question.

The southern boundary of the Bayan Har Block consists of three main faults: the Fenghuoshan fault zone in the northwest segment, the Ganzi-Yushu fault zone in the middle segment, and the Xianshuihe fault zone in the southeast (Figure 15C). We observe that the kinematic characteristics along the southern boundary of the Bayan Har Block are different along the strike in two aspects (Figure 15C). First, the kinematic characteristics of the structure change from reverse strike-slip in the northwest segment to strike-slip in the middle segment and gradually to normal strike-slip in the southwest segment. In addition, the sinistral slip rate increases from the northwest section to the southeast (Figure 15C). The GPS data also show that the northward motion of the plateau decreases across the Fenghuoshan thrust-fold belt, which hints that the belt is still active (Zhang et al., 2004). Obviously, these kinematical characteristics cannot be explained simply by the eastward extrusion. Block rotation, caused by the dextral shear between the Qinghai-Tibet Block and Yangtze block, may lead to a gradual increase in the slip rate from the NW segment to the SE segment along the structure. Thus, the strain partition along the boundary is crucial to discuss the possible transfer process from north-south shortening and east-west extension in the Fenghuoshan segment to oblique rotation in the middlesouth segment.

Here, we propose a simple strain-distribution model to explain the tectonic characteristics mentioned above (Figure 15C). The oblique convergence of the Qiangtang Block to the south is $\sim 22-28 \mathrm{~mm} / \mathrm{yr}$ based on recent GPS observations (ShenLiao and Wang, 2009). This oblique motion of the Qiangtang Block might be partitioned into the Fenghuoshan Fault Zone with a slip rate of $\sim 3 \mathrm{~mm} / \mathrm{yr}$, the Ganzi-Yushu Fault Zone sinistral slip rate of 6-10 mm/yr, and normal-strike-slip faulting at the Xianshuihe Fault Zone with a slip rate greater than $13 \mathrm{~mm} / \mathrm{yr}$ (Figure 15C). Two possible reasons may be responsible for this strain-allocation process: the strike of the fault obviously changes from nearly $\mathrm{E}-\mathrm{W}$ in the northwest to nearly N-S in the southeast, and the elevation of the terrain remarkably decreases from $\sim 6,000 \mathrm{~m}$ in the northwest to $\sim 3,000 \mathrm{~m}$ in the southeast. The strike variation is possibly the dominant reason for the kinematic change from compression to extension, while the decrease in altitude may also be more favorable for the material to extrude eastward. In summary, we suggest that the oblique convergence of the Qiangtang Block might be accommodated mainly by clockwise rotation through repeated left-lateral strike-slip seismic motion along the southern boundary of the Bayan Har Block in the central Tibetan Plateau, although the detailed transfer mechanism still needs more investigation. 


\section{CONCLUSION}

Based on geologic observations, historical literature reviews, geomorphic mapping, trench logging, and sample dating, we conclude that 1) the CE 1738 Dangjiang earthquake produced an $\sim 100 \mathrm{~km}$-long surface rupture zone that includes diagrammatic features of recent displacement, such as consistently offset or deflected gullies, linear scarps and troughs, sag ponds, en echelon fractures, and pressure ridges; 2) the magnitude of the CE 1738 Dangjiang earthquake is reestimated as $M 7.6$ with average and maximum strike-slip displacements of $\sim 2.1 \pm 0.1 \mathrm{~m}$ and $\sim 3.3 \pm 0.1 \mathrm{~m}$, respectively; 3 ) the DJF has undergone multiple seismic faulting events in the Holocene, and the linear fitting surface displacement rate with a $95 \%$ confidence interval is $\sim 6.3 \pm$ $1.9 \mathrm{~mm} / \mathrm{yr}$; 4) oblique convergence of the Qiangtang Block might be accommodated by the clockwise rotation of block through the repeated left-lateral strike-slip movements along the southern boundary of the Bayan Har Block in central Tibetan Plateau.

\section{DATA AVAILABILITY STATEMENT}

The original contributions presented in the study are included in the article/Supplementary material, further inquiries can be directed to the corresponding author.

\section{REFERENCES}

Allen, C. R., Zhuoli, L., Hong, Q., Xueze, W., Huawei, Z., and Weishi, H. (1991). Field Study of a Highly Active Fault Zone: The Xianshuihe Fault of Southwestern China. Geol. Soc. America Bull. 103, 1178-1199. doi:10.1130/0016-7606(1991)103<1178: fsoaha $>2.3 . c 0 ; 2$

Arne, D., Worley, B., Wilson, C., Chen, S. F., Foster, D., Luo, Z. L., et al. (1997). Differential Exhumation in Response to Episodic Thrusting along the Eastern Margin of the Tibetan Plateau. Tectonophysics 280, 239-256. doi:10.1016/ s0040-1951(97)00040-1

Chen, L., Wang, H., Ran, Y., Sun, S., Su, G., Wang, J., et al. (2010). The Ms 7.1 Yushu Earthquake Surface Ruptures and Historical Earthquakes. Chin. Sci. Bull 13, 1200-1205.doi:10.1007/s11434-010-4079-2

Compiling Committee of Annals of Qinghai Province (1998). Annals of Civil Administration of Qinghai Province (In Chinese). Anhui: Huanghsan Press.

Deng, Q., Ran, Y., Yang, X., Min, W., and Chu, Q. (2007). Active Tectonics Map of China (1:4 Million). Beijing: Seismological Press, 2-3pp.

Deng, Q., Yu, G., and Ye, W. (1992). Relationship between Earthquake Magnitude and Parameters of Surface Ruptures Associated with Historical Earthquakes. Res. Active Fault 2, 247-264.

Deng, Q., Zhang, P., Ran, Y., Yang, X., Min, W., and Chu, Q. (2002). Basic Characteristics of Active Tectonicsof China (In Chinese). Sci. China (Series D) 32, 1020-1030.doi:10.1360/03yd9032

Editorial Board of Annals of Sichuan Province (1998). Annals of Sichuan Province: Annals of Earthquake. Chengdu, China: Sichuan People Press, 382.

Fossen, H. (2016). Structural Geology. Cambridge: University Printing House Press, 187-188pp.

Gu, G. (1983). The Catalog Of Chinese Historic Strong Earthquakes (B.C.1831-AD 1969) (In Chinese). Beijing: Science PublishingHouse, 128-129pp.

Huang, X. M., Du, Y., and He, Z. T. (2015a). Late Quaternary slip rate of the Batang Fault and its strain partitioning role in Yushu area, Central Tibet. Tectonophysics 653, 52-67. doi:10.1016/j.tecto.2015.03.026

\section{AUTHOR CONTRIBUTIONS}

ZY: Conceptualization, Methodology, Acquisition of the financial support, Writing-Reviewing and Editing. NY: Original draft preparation and presentation of the published work. PX: Visualization, Field geological survey and analysis and processing of age samples. CX: Surface geomorphology survey and analysis and data collection, Validation.

\section{FUNDING}

This work was sponsored by the Second Tibetan Plateau Scientific Expedition and Research Program (STEP) (2019QZKK0901).

\section{ACKNOWLEDGMENTS}

We are grateful to professors Pei-zhen Zhang, Wen-jun Zheng, Dao-yang Yuan, Chuan-you Li, and Jun Shen for their great assistance in this research. The discussion with Rong-jun Zhou, $\mathrm{Hu}$ Wang, and Yan-bao Li greatly deepened our understanding of the active tectonics and earthquake potential assessment along the western portion of the Ganzi-Yushu Fault Zone. We would like to especially acknowledge the editors and reviewers for their constructive comments and suggestions, which greatly improved this paper.

Institute of Geophysics, China Seismological Bureau (1990). Atlas of Historic Earthquakes in China (Qing Dynasty). Beijing: China Cartographic Publishing House, 24pp.

King, R. W., Shen, F., Clark Burchfiel, B., Royden, L. H., Wang, E., Chen, Z., et al. (1997). Geodetic Measurement of Crustal Motion in Southwest China. Geol 25, 179-182. doi:10.1130/0091-7613(1997)025<0179:gmocmi>2.3.co;2

Li, M. F., and Xing, C. Q. (1995). Study on the activity of Yushu fault. Seismol. Geol. $17,218-224$.

Li, C.-y., Pang, J.-z., and Zhang, Z.-q. (2012). Characteristics, Geometry, and Segmentation of the Surface Rupture Associated with the 14 April 2010 Yushu Earthquake, Eastern Tibet, China. Bull. Seismological Soc. America 102, 1618-1638. doi:10.1785/0120110261

Li, Y. H., Wang, H., and Chen, L. (2016). The Surface Rupture Remains along the Dangjiang Segment of Garze-Yushu Fault and the $1738 \mathrm{CE}$ Earthquake. Technology earthquake 11, 207-217. doi:10.11899/zzfy20160204

Lin, A., Fu, B., Guo, J., Zeng, Q., Dang, G., He, W., et al. (2002). Co-Seismic StrikeSlip and Rupture Length Produced by the 2001 M S 8.1 Central Kunlun Earthquake. Science 296, 2015-2017. doi:10.1126/science.1070879

Lin, A., Rao, G., Jia, D., XiaojunWu, X., Yan, B., and Ren, Z. (2011). Co-seismic Strike-Slip Surface Rupture and Displacement Produced by the 2010 MW 6.9 Yushu Earthquake, China, and Implications for Tibetan Tectonics. J. Geodynamics 52, 249-259. doi:10.1016/j.jog.2011.01.001

Liu, Y., Xu, C., Li, Z., Wen, Y., and Forrest, D. (2011). Interseismic Slip Rate of the Garze-Yushu Fault belt in the Tibetan Plateau from C-Band InSAR Observations between 2003 and 2010. Adv. Space Res. 48, 2005-2015. doi:10.1016/j.asr.2011.08.020

McCalpin, J. P. (2009). Paleoseismology. California: Academic Press, 10-11pp.

Michale, T., and Yin, A. (2009). Active Structures of the Himalayan-Tibetan Orogen and Their Relationships to Earthquake Distribution, Contemporary Strain Field, and Cenozoic Volcanism. Geosphere 3, 199-214. doi:10.1130/ges00217.s1

Molnar, P., and Qidong, D. (1984). Faulting Associated with Large Earthquakes and the Average Rate of Deformation in central and Eastern Asia. J. Geophys. Res. 89, 6203-6227. doi:10.1029/jb089ib07p06203 
Molnar, P., and Tapponnier, P. (1975). Cenozoic Tectonics of Asia: Effects of a Continental Collision: Features of Recent continental Tectonics in Asia Can Be Interpreted as Results of the India-Eurasia Collision. Science 189, 419-426. doi:10.1126/science.189.4201.419

Peng, H., Ma, X., Bai, J., and Du, D. (2006). Characteristics of Quaternary Activities of the Ganze-Yushu Fault Zone. J. Geomech. 12, 295-304. doi:10.21203/rs.3.rs$793347 / \mathrm{v} 1$

Roger, F., Calassou, S., Lancelot, J., Malavieille, J., Zhiqin, M. X., Ziwen, H., et al. (1995). Miocene Emplacement and Deformation of the Konga Shan Granite (Xianshui He Fault Zone, West Sichuan, China): Geodynamic Implications. Earth Planet. Sci. Lett. 130, 201-216. doi:10.1016/0012-821x(94)00252-t

Rowley, D. B. (1996). Age of Initiation of Collision between India and Asia: a Review of Stratigraphic Data. Earth Planet. Sci. Lett. 145, 1-13. doi:10.1016/ s0012-821x(96)00201-4

ShenLiao, Z.-K., Zhang, J. P., Wan, Y., Wang, M., Bürgmann, R., Zeng, Y., et al. (2009). Slip Maxima at Fault Junctions and Rupturing of Barriers during the 2008 Wenchuan Earthquake. Nat. Geosci 2, 718-724. doi:10.1038/ngeo636

Tang, R., Huang, Z., Qian, H., Deng, T., Jiang, L., Ge, P., et al. (1984). On the Recent Tectonic Activity and Earthquake of the Xianshuihe Fault Zone, in a Collection of Papers of International Symposium on continental Seismicity and Earthquake Prediction. Beijing: China Seismological Press, 347-363pp.

Tapponnier, P., Zhiqin, X., Roger, F., Meyer, B., Arnaud, N., Wittlinger, G., et al. (2001). Oblique Stepwise Rise and Growth of the Tibet Plateau. Science 294, 1671-1677. doi:10.1126/science. 105978

Thatcher, W. (2007). Microplate Model for the Present-Day Deformation of Tibet. J. Geophys. Res. 112, B101401. doi:10.1029/2005jb004244

Wang, E., and Burchfiel, B. C. (2000). Late Cenozoic to Holocene Deformation in Southwestern Sichuan and Adjacent Yunnan, China, and its Role in Formation of the southeastern Part of the Tibetan Plateau. Geol. Soc. America Bull. 112, 413-423. doi:10.1130/0016-7606(2000)112<413:Icthdi >2.0.co;2

Wang, E., Burchfiel, B., Royden, L., Chen, L., Chen, J., Li, W., et al. (1998). The Cenozoic Xianshuihe-Xiaojiang, Red River, and Dali Fault Systems of Southwestern Sichuan and central Yunnan China. Geol. Soc. America Spec. Paper, 327. 108.

Wang, M., and Shen, Z. (2020). Present-day Crustal Deformation of continental China Derived from GPS and its Tectonic Implications. J. Geophys. Res. Solid Earth 125, e2019JB018774. doi:10.1029/2019jb018774

Wang, Q., Zhang, P.-Z., Freymueller, J. T., Bilham, R., Larson, K. M., Lai, X. a., et al. (2001). Present-day Crustal Deformation in China Constrained by Global Positioning System Measurements. Science 294, 574-577. doi:10.1126/ science.1063647

Wang, S., Fan, C., Wang, G., and Wang, E. (2007). Late Cenozoic Deformation along the Northwestern Continuation of the Xianshuihe Fault System, Eastern Tibetan Plateau. Geol. Soc. America Bull. 120, 312-327. doi:10.1130/B25833.1

Wang, Y., Wang, M., Shen, Z., Ge, W., Wang, K., Wang, F., et al. (2011). Interseismic Deformation Field of the Ganzi-Yushu Fault before the 2010 Yushu Earthquake. Seismology Geology. 33, 525-532. doi:10.1016/j.tecto.2012.03.026

Wells, D., and Coppersmith, K. (1994). New Empirical Relations Among Magnitude, Rupture Length, Rupture Width, Rupture Area and Surface Displacement. Bull. Seismological Soc. America 84, 974-1002.

Wen, X.-Z., Ma, S.-1., Xu, X.-w., and He, Y.-n. (2008). Historical Pattern and Behavior of Earthquake Ruptures along the Eastern Boundary of the SichuanYunnan Faulted-Block, Southwestern China. Phys. Earth Planet. Interiors 168, 16-36. doi:10.1016/j.pepi.2008.04.013
Wen, X., Xu, X., Zheng, R., Xie, Y., and Wan, C. (2003). Average Slip Rate and Modern Seismic Rupture of the Ganzi-Yushu Fault. Sci. China (Series D) 33 (Suppl. 1), 199-207. doi:10.3969/j.issn.1674-7240.2003.z1.022

Wu, J., Huang, X., and Xie, F. (2017). Deformation of the Most Recent Coseismic Surface Ruptures along the Garzê-Yushu Fault Zone (Dangjiang Segment) and Tectonic Implications for the Tibetan Plateau. Acta Geologica Sinica - English Edition 91, 443-454. doi:10.1111/1755-6724. 13110

Xu, G., and Kamp, P. J. J. (2000). Tectonics and Denudation Adjacent to the Xianshuihe Fault, Eastern Tibetan Plateau: Constraints from Fission Track Thermochronology. J. Geophys. Res. 105, 19231-19251. doi:10.1029/ 2000jb900159

Xu, X. W., Wen, X. Z., and Zheng, R. Z. (2003a). The latest tectonic deformation patterns and dynamic sources of active blocks in Sichuan-Yunnan region. China Sci. 33 (04), 151-162. doi:10.3969/j.issn.1674-7240.2003.z1.022

Yin, A. (2010). Cenozoic Tectonic Evolution of Asia: A Preliminary Synthesis. Tectonophysics 488, 293-325. doi:10.1016/j.tecto.2009.06.002

Yu, Z., Yin, N., Shu, P., Li, J., Wei, Q., Min, W., et al. (2018). Late Quaternary Paleoseismicity and Seismic Potential of the Yilan-Yitong Fault Zone in NE China. J. Asian Earth Sci. 151, 197-225. doi:10.1016/j.jseaes.2017. 10.038

Yuan, D., Lei, Z., He, W., and Liu, X. (2011). Research of Yushu Earthquake in 1738 $\mathrm{AD}$ in Qinghai Province and Discussion Their Relationship with Yushu Earthquake Ms 7.1 in 2010. Prog. Geophys. 26, 1950-1958.doi:10.3969/j.issn. 1004-2903.2011.06.008

Zhang, P.-Z., Shen, Z., Wang, M., Gan, W., Bürgmann, R., Molnar, P., et al. (2004). Continuous Deformation of the Tibetan Plateau from Global Positioning System Data. Geol 32, 809-812. doi:10.1130/ g20554.1

Zhang, P., Deng, Q., Zhang, G., Ma, J., Gan, W., Min, W., et al. (2003). Active Tectonic Blocks and strong Earthquakes in continental China. Sci. China (Series D) 46, 13-24. doi:10.1360/03ye0003

Zhou, R., Ma, S., and Cai, C. (1997). Late Quaternary Active Features of the Ganzi-Yushu Fault Zone. Earthquake Res. China 12, 250-260.

Zhou, R., Wen, X., Cai, C., and Ma, S. (1996). Recent Earthquakes and Assessment of Seismic Tendency on the Ganzi-Yushu Fault Zone. Seismol.Geol. 19, 115-124.

Conflict of Interest: The authors declare that the research was conducted in the absence of any commercial or financial relationships that could be construed as a potential conflict of interest.

Publisher's Note: All claims expressed in this article are solely those of the authors and do not necessarily represent those of their affiliated organizations, or those of the publisher, the editors and the reviewers. Any product that may be evaluated in this article, or claim that may be made by its manufacturer, is not guaranteed or endorsed by the publisher.

Copyright (c) $2022 \mathrm{Yu}$, Yin, Xiao and Chen. This is an open-access article distributed under the terms of the Creative Commons Attribution License (CC BY). The use, distribution or reproduction in other forums is permitted, provided the original author(s) and the copyright owner(s) are credited and that the original publication in this journal is cited, in accordance with accepted academic practice. No use, distribution or reproduction is permitted which does not comply with these terms. 